
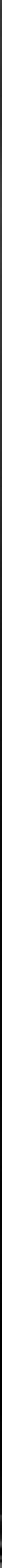

Nina Callaghan, Rabyn Foley and Mark Swilling (EDITuRS) 


\section{STEALING FROM THE POOR: STATE CAPTURE AT SASSA}

Robyn Foley

If you've got to choose between paying the grants and irregular. And if the country's going to burn on the 1st of April and the irregular, I choose the country not to burn. (SABC Digital News, 2017)

The statement above, made by the then South African Social Security Agency (SASSA) CEO Thokozani Magwaza during a presentation to the Parliamentary Portfolio Committee on Social Development (PCSD), highlights the two crises which were unfolding before South Africa's eyes in early 2017. The first, which has become known as the SASSA-Gate crisis, was the potential risk that some 17 million grant recipients would not receive the grants which they depend on come 1 April 2017 when the invalid contract with Cash Paymaster Services (CPS) was set to end - an eventuality which by that point was unthinkable. So unthinkable was this idea that admittedly almost everyone at the time was in agreement that this would not come to pass and that one way or another there was no option but to ensure the continued payments of grants. Yet, until there was clarity on how grants would be paid, all the assurances given by the President and the Minister provided little comfort to the millions of children who were at risk of going hungry, nor would that alleviate the anxiety of the elderly who could be left homeless due to not being able to pay their rent. Had it materialised, this would have been a socio-political crisis of mammoth proportions.

In response to this eminent threat, a collective of civil society organisations, led by the Black Sash Trust, approached the Constitutional Court to intervene. The urgency of the court application, given the limited time available for addressing the imminent crisis, was not disputed, nor was the required outcome in terms of CPS needing to continue to pay grants. In the court application, the Minister and SASSA declared that "CPS is the only entity capable of paying grants for the foreseeable future after 31 March 2017", a situation which the court did not take kindly to (Constitutional Court of South Africa, 2017b). Ultimately, the court ruled that the initial 2012 invalid contract between SASSA and CPS would continue for a year and thus the crisis was averted. 
The underlying cause of this crisis, however, is the second crisis - the governance crisis. It is the story of this governance crisis that this chapter seeks to unpack. As the Constitutional Court concluded:

The constitutional right to social assistance that for many, especially children, the elderly and the indigent, provide the bare bones of a life of dignity, equality and freedom is directly involved, across the land. The conduct of the Minister and SASSA has created a situation that no one could have contemplated: the very negation of the purpose of this Court's earlier remedial and supervisory order. The matter can be decided on facts that are not disputed. Due to the time constraints of the emergency created by the Minister and SASSA, the forum for effective final relief is this Court. (Constitutional Court of South Africa, 2017b)

In July 2018, the State Capacity Research Project released one of the follow-on case studies to the Betrayal of the Promise, titled How One Word Can Change the Game: Case Study of State Capture and the South African Social Security Agency (Foley \& Swilling, 2018). The report provides, in intricate detail, an account of how SASSA was captured and the implications thereof. This chapter seeks to expand on analysis of that case study by briefly describing the key events round which the SASSA case study is centred; outlining the critical aspects that make it case of state capture (as defined in Introduction); unpacking the costs that have resulted from the capture of SASSA and lastly highlight how the SASSA case study also serves potentially as an example of how state capture to some extent was curtailed.

\subsection{EVOLUTION OF THE GRANTS PAYMENT SYSTEM AND THE SASSA-GATE CRISIS}

\subsubsection{Background on SASSA and the Social Grant Payment System}

In 2004, the legislation that formalised South Africa's social security systems and established the national agency which would be responsible for administering grants, was signed and promulgated. The Social Assistance Act 13 of 2004 (Republic of South Africa, 2004a) and the South African Social Security Agency Act 9 of 2004 (Republic of South Africa, 2004b) are the two main pieces of legislation that outlines the requirements and parameters for social grants and the institutional structure by which they are distributed. The primary objective of the South African Social Security Agency (SASSA, also referred to as the Agency) was to centralise and standardise the payment and administration of grants. Over and above this legislation, SASSA is also required to be governed by all legislation related to the operation and governance of any state run entity, including to the Public Finance Management Act, 1999 (Act No. 1 of 1999) (Republic of South Africa, 1999). 
Prior to the establishment of SASSA, the payments of grants was fragmented as the responsibility for grants resided with each of the nine provinces, and payment methods were inconsistent and inefficient. The majority of grants were paid in cash through contracted service providers, each conforming to separate and varying service level agreements and providing different models for payment (Constitutional Court of South Africa, 2013).

In 2006, SASSA inherited the fragmented and non-standardised social grants service provider contracts for the various provinces. The method and manner in which grants were distributed to recipients varied greatly between the various service providers, as did the costs and the terms and conditions of service contracts. In line with the recommendations laid out by the Taylor Committee, SASSA undertook to centralise the payment of grants. On 23 February 2007, the Agency issued its first Request for Proposal (RFP) for the "Provision of a Payment Service". Nine bids were received for the tender, however, in its final report submitted to the CEO of SASSA on 25 September 2008 (almost a year and a half after being issued), the Bid Adjudication Committee (BAC) concluded that the tender should be cancelled (Adjudication Committee, 2008). It later emerged that there was allegedly an attempt to bribe the chair of the BAC, Adv. Arendse, by someone claiming to represent CPS. The allegation has been profusely denied (Arendse, 2009; Bainbridge, 2009; McKune, 2012; Bejoy, 2016).

In 2009, just prior to Zuma appointing Bathabile Dlamini as Minister of the Department of Social Development (DSD), SASSA and South African Post Office (SAPO) had entered into a Memorandum of Understanding (MOU) which would see the two SOEs partnering to develop government's capacity for the payments of social grants. Being aggrieved by the agreement between SASSA and SAPO, as well as other agreements between SASSA and certain banks to subsidise grant recipients' banking fees, CPS instituted several legal cases against SASSA. In 2011, after having the High Court find in favour of CPS, the Supreme Court of Appeal ruled that the agreement between SAPO and SASSA was valid (Supreme Court of Appeal of South Africa, 2011). This outcome would, however, be of no consequence as in the month that followed SASSA would initiate a fresh tender process for identifying a service provider for the payment of grants. When CPS won the 2012 contract, it ceased to pursuing the litigation, however, when it became evident that CPS would no longer be paying social grants following the SASSA-Gate crisis, Net1 lodged an unsuccessful claim against SASSA for almost R1.3bn, seemingly based on the litigation that it had dropped after having been awarded the 2012 tender (Quintal, 2019).

\subsubsection{The Invalid 2012 Contract: The Original Sin}

In 2010, arguably the first visible strategic move to repurpose state institutions took place in the form of the first cabinet reshuffle, in which then President Zuma appointed 
Bathabile Dlamini (President of the ANC Women's League and strong Zuma ally) as Minister of the Department of Social Development (DSD). In 2011, a new tender process was initiated and in January 2012 the contract for the provisioning of social grant payments was awarded to Cash Paymaster Services (Pty) Ltd.

Minister Dlamini appointed Ms Virginia Petersen as CEO of SASSA on 21 April 2011 (Cabinet, 2011), four days after the new RFP was released on 17 April. The importance of specifying these dates is to highlight that in terms of exposure to the complexities of the services that SASSA was seeking to acquire and the technical complexities around how the RFP was constructed, it would be reasonable to assume that Ms Petersen was most likely not in a position to make executive interventions in the bidding process. It was Petersen who, on 10 June, issued Bidders Notice 2, which was purportedly intended to clarify the requirements for biometric verification for payment transactions. The significant change comes down to the change of just one word, where the authentication of life for the monthly payment of a grant to a recipient (read biometrics) had gone from being a "preferred" requirement to a "must". Both the competing bidders (AllPay and CPS) provided for the use of fingerprint biometrics in the process of beneficiary enrolment and reconciliation (proposed by both AllPay and CPS). However, as mainstream payment methods were not yet enabled for biometric verification, AllPay was not able to meet this change in requirement. It was only CPS's proposal that offered an alternative method of biometric verification in the form of voice biometric technology, which was never properly implemented (Cape Times, 2014). Ultimately, it was this changing of just one word in the technical requirements that resulted in CPS being awarded the tender on 17 January 2012 (Constitutional Court of South Africa, 2013).

A number of the losing bidders, particularly the other provincial service providers (hereinafter referred to as 'AllPay'), were aggrieved by the bid evaluation process and the awarding of the contract to CPS, and collectively resolved to institute litigation against the DSD, SASSA, and CPS. The litigation process ultimately resulted in the case being heard by the Constitutional Court. In November 2013, the court ruled that the award of the tender to provide services for payment of social grants to CPS was constitutionally invalid and in April 2014 a remedial order was handed down, where the court suspended the declaration of invalidity. The declaration was based on the premise that a new tender would be awarded after a proper procurement process. To ensure the payment of grants was not interrupted, CPS would continue to provide payment services and the invalidity of the contract was suspended. SASSA was ordered to report to the court on progress in respect of the new tender process and its outcome (Constitutional Court of South Africa, 2013, 2014). 
Following the two attempts to find a solid solution for distributing grants, the first being abandoned in 2008 and the second being found by the Constitutional Court to be invalid, the DSD set about the task of attempting to once again carve out a way forward. A third tender process was initiated but was then later abandoned due to non-responsive bids. It was suggested at the time that the tender was engineered to fail, citing two specifications that made the tender commercially unviable. The first was the price, where SASSA had stipulated a maximum fee of R14.50 per recipient per month, which is an $11.8 \%$ decrease on the fee that CPS was charging, and the second being the biometric (proof of life) requirement, which CPS initially approached the courts to have SASSA revise (Sole \& McKune, 2017).

In 2015, SASSA then decided that it would endeavour to take over the payment of grants itself. In order to achieve this SASSA, on instruction by minister Dlamini based on recommendation from her Ministerial Advisory Committee (MAC), appointed external advisors to oversee the planning and development of SASSA's capabilities to fulfil this function (referred to as the work streams) (Constitutional Court of South Africa, 2017a). However, in early 2017, it emerged that there was no feasible plan for how grants would continue to be paid come 1 April 2017 (which was the original end date for the invalid CPS contract).

\subsubsection{The SASSA-Gate Crisis}

Ultimately, the court ruled that the invalid contract between SASSA and CPS would continue for a year (with changes to pricing being determined by National Treasury) and that the court would resume its oversight role by appointing a Panel of Experts to monitor the progress in finding a solution to take over the payments from CPS by 1 April 2018 (Constitutional Court of South Africa, 2017b). The fact that the court had to appoint such a panel as a governance mechanism reveals how deeply dysfunctional the Executive, as well as the oversight bodies of parliament, had become in the eyes of the court.

The sequence of events which led to the Black Sash approaching the Constitutional Court, traces back to its involvement in the Ministerial Task Team (MTT), which was focusing on the issues of irregular deductions from social grants. Through its engagements with Minister Dlamini in September of 2016, just seven months before SASSA was due to take over the payment of grants, it became apparent to some in the MTT that there did not appear to be any resolve as to how this transition was to take place. The Black Sash (as co-Chair of the MTT) sent a letter to the Minister requesting that an update be given on SASSA's progress regard the taking over of grant payments - a request that was declined (Dangor, 2017a). When the Black Sash 
launched its litigation against SASSA and DSD, the MTT was disbanded and all amicable engagement with both the agency and the department came to end.

A Section 38 Inquiry set up by the Constitutional Court to get to the bottom of how the crisis had materialised and was held in early 2018. It resulted from the request by Black Sash for the Constitutional Court to consider assigning a personal cost order to Dlamini as a form of accountability for dereliction of duty as the executive authority - under whose watch SASSA and in turn the state, was unable to fulfil its legal constitutional mandate. As noted in the Constitutional Court ruling:

... there are reasonable grounds for investigating whether this Court's
remedial order was disregarded and, if so, whether this was done wilfully...
The Minister bears the primary responsibility to ensure that SASSA fulfils its
functions. She appoints its CEO. There is little the CEO can do without her
direction. Attempts to obtain evidence of what steps she took after AllPay 2
to ensure that beneficiaries would continue to be well catered for drew a
blank. (Constitutional Court of South Africa, 2017b, p. 38)

Although not putting forward any definitive recommendations, the comments by Judge Ngoepe in a report submitted to the Constitutional Court following the Section 38 Inquiry, were scathing in regard to the conduct of the former Minister. As reported in a Mail \& Guardian article (Herman, 2018), Ngoepe's report indicates that "Dlamini was evasive", her explanation on why she did not disclose the appointment of the individuals to work streams was "unconvincing" and the "appointment of work streams and their role was central to the whole exercise of meeting the deadline. Therefore, in dealing with any aspect relating to the crisis, it is difficult to understand how the minister could have justifiably left out the issue of the appointment of work stream". Ultimately the Constitutional Court would rule, in a ground-breaking judgment, that Dlamini be held personally liable for $20 \%$ of the Black Sash case litigation costs and that the NPA should consider if there is a possible case of perjury in relation to the ministers testimony at the Section 38 Inquiry (Constitutional Court of South Africa, 2018b).

Through the court proceeding, the subsequent Section 38 Inquiry and the numerous investigative reports in the media, it is clear that within government there was no agreement on what the future payment system should entail or how this crisis was going to be averted. There were essentially two different approaches, and these make visible the stark contrast between the constitutional and shadow state. The first approach (promoted by DSD officials Zane Dangor and Sipho Shezi, together with the newly appointed CEO of SASSA Thokozani Magwaza) was to approach the Constitutional Court and try limiting the reliance of SASSA on CPS as much as possible, with the main objective being to remove CPS from the grant payment system within a year. The second approach (preferred by Dlamini, enabled by the parallel work 
streams/external consultants) was to enter into a new, undoubtedly illegal, contract with CPS, with new negotiated higher rates for an extended period of at least two years. An important aspect of this second approach was that SASSA would not seek to approach the Constitutional Court prior to entering a new, undoubtedly unlawful, contract with CPS. It would instead only inform the court after the fact. This approach was in direct opposition to the recommendations presented to the agency and DSD, in three separate written legal opinions (Foley \& Swilling, 2018).

During the institutional turmoil in the lead up to and following the March 2017 Constitutional Court ruling, those that apposed Minister's approach were removed from the offices of DSD and SASSA. Zane Dangor had resigned from the post of Director General of DSD in March of 2017 and by 10 April 2017, Minister Dlamini's long-time special adviser, Sipho Shezi, was fired (Thamm, 2017a). Just prior to leaving SASSA on 17 July 2017, Thokozani Magwaza (then CEO of SASSA) terminated the contracts of the work streams after National Treasury had declared their appointment as irregular. At the same time, Magwaza also received approval from National Treasury, allowing for a deviation from the standard procurement process, which would allow for the provisioning of services between and within different government entities. Having received this approval, Magwaza signed a cooperation agreement between SASSA and SAPO (Dzonzi, 2017).

On 19 July, Dlamini replaced Magwaza with "one of her close supporters and a fellow member of the ANC Women's League”, Pearl Bhengu (Ensor, 2017). With all three opponents (Dangor, Shezi, and Magwaza) out of the way and an ally now appointed as acting CEO of SASSA, the doors were reopened for the Minister to ensure that she got what she wanted - at least until parliament intervened.

Towards the end of October 2017, the Panel of Experts presented a damning report to the Constitutional Court regarding the conduct of SASSA officials responsible for ensuring a grant payment system is in place by April 2018. The panel did not receive a copy of the SAPO RFP despite requesting it on numerous occasions from the department. They indicated that "the absence of a comprehensive implementation plan for SASSA's stated objectives providing adequately for risk management, risk mitigation and proposed alternatives should the 'course of action fail or an exit plan in respect of CPS' presents a 'serious risk'” (Thamm, 2017b).

Alarmed by the report by the Panel of Experts and the fact that SASSA had missed four self-imposed deadlines for signing a contract with SAPO, Standing Committee on Public Accounts (SCOPA) and the Social Development Portfolio Committee called the DSD, SASSA, and SAPO to provide parliament with an update as to what had happened and what was intended for the way forward. As meeting after meeting unfolded, it became clear that the disconnect between SASSA and SAPO 
would require an intervention. What was revealed through these meetings was that, following Magwaza's exit from SASSA, there appears to have been a marked turn for the worse in the relationship between the two SOEs. After the two state entities could not reach an agreement, the portfolio committees combined their efforts and called in National Treasury to establish what had transpired. On 8 November 2017, those representing the Inter-Ministerial Committee (IMC) on Comprehensive Social Security and Minister Jeff Radebe (who by then was the chair of the committee, even though it had been announced in March that President Zuma would undertake this role) reported back to parliament that it had set up a task team to intervene and that an agreement would be concluded by 17 November (Foley \& Swilling, 2018).

When the joint standing committee's in parliament intervened in November 2017, there was little time (less than 5 months) remaining for SAPO to mobilise the necessary resources to meet the looming deadline of 1 April 2018 for taking over the payment of social grants. With pressure from IMC on DSD and SASSA, a contract was signed with SAPO on 10 December 2017 and the difficult task of transitioning the grant payment system commenced (Herman, 2017).

Out of the four principle functions outlined in the original RFP from SASSA, SAPO was awarded three, namely: the development of an integrated payment system, providing banking services and management of card production, all of which were required to handle beneficiaries' biometric data (Foley \& Swilling, 2018, p. 60). The remaining function, which under Dlamini it was indicated would be put out on a standalone tender process, was the servicing of cash pay points. With only a few months to finalise the procurement process and contract negotiations, yet alone enact an operational transition, many were aware that it was highly unlikely that a replacement for CPS would be in a position to take over the cash payments function come April 2018. SASSA, however, would only approach the Constitutional Court with this information on the eve of the deadline. On 23 March 2018, the invalid contract between SASSA and CPS was yet again extended for an additional six months, to ensure that CPS continued to provide cash payment services to beneficiaries during the transition to the new SASSA/SAPO payment system (Constitutional Court of South Africa, 2018a).

In the ruling made by the Constitutional Court on 23 March 2018, required for the extension, significant criticism was again levied against Dlamini, together with Pearl Bhengu (the acting CEO of SASSA at the time). The criticism, similar to the previous judgment, was due to the Agency's inability to meet the initial March 2017 deadline (Constitutional Court of South Africa, 2018c). Both Dlamini and Bhengu were instructed to explain why they should not be held liable for the costs related to this second extension. Ultimately, both were found to be responsible for the extension, 
however, only Dlamini had a personal cost order placed against her following the outcomes of the Section 38 Inquiry (Saba, 2018).

\subsection{SASSA AS CASE OF STATE CAPTURE}

Since the 2012 tender award to CPS, there has been a plethora of investigative reporting on allegations of corruption, some emanating out of the court filings in the litigations. Most of the allegations relate to Minister Dlamini's indirect connections to the Black Economic Empowerment partners of CPS and its US listed holding company Net 1 UEPS Technologies Inc. (Net1). There have also been significant questions raised around the role which the external advisors (the work streams) played in the decisions and actions which culminated in the SASSA-Gate crisis.

It is important to note that following the initial Constitutional Court ruling in 2013, due to Net1 being a US-listed company, both the Federal Bureau of Investigation (FBI), under instruction from the US DOJ and the US markets regulator, the Securities and Exchange Commission (US SEC), as well as the Hawks on two cases, undertook investigations into the allegations of corruption levelled against Net1/CPS. The SEC closed its investigation in May 2015 with the disclaimer that this "must in no way be construed that the party has been exonerated" (US SEC, 2015). In July 2017, US DOJ also closed its investigation with a similar caveat: "If the Department learns additional information, it may reopen its inquiry" (US DOJ, 2017). At the end of 2015 it was announced that the Hawks had investigated allegations of corruption levelled against Net1/CPS and brought their findings before two separate prosecutors, who decided not to prosecute (Chopra, 2015). There are no details surrounding the cases or the reasons for deciding not to prosecute, but given the wealth of information that has emerged since then (in terms of both the SASSA case and the seemingly compromised actions of the Hawks and NPA under the Zuma administration), there is still potentially a case that could be pursued.

Most if not all of the allegations have been denied by those implicated, sometimes accompanied with obscure or shallow justification. It is, however, worth noting that Dlamini herself seems to indicate that there is more to the SASSA-CPS contract than has been made public. In her rambling resignation letter as a representative for the ANC in the National Assembly, after not being appointed to the new cabinet following the May 2019 elections, Dlamini indicated that in her defence there are " $[\mathrm{t}]$ hose that made profit through CPS through by their wives are known, but because they are well respected by the organization. Nothing has been said to them. I have been made a scape goat and an easy target" (Dlamini, 2019, p. 4). 


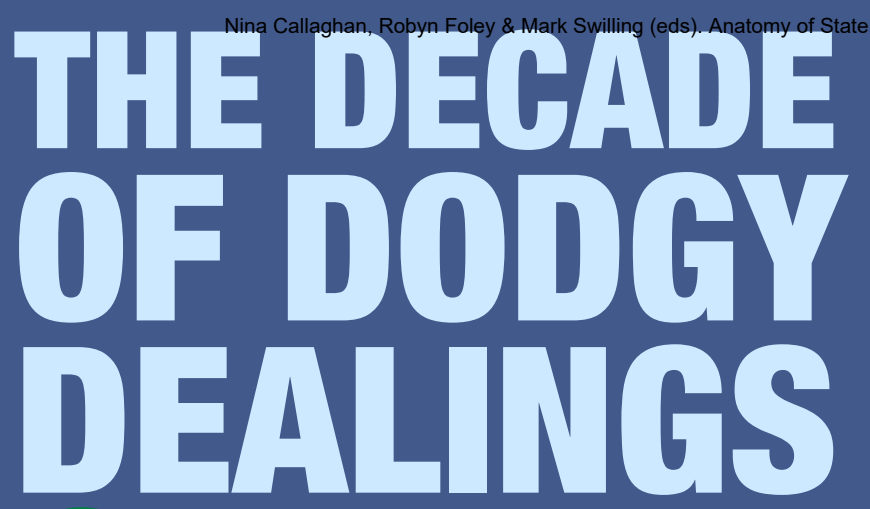

\section{COLLUSIOU \\ BRIBERYY} AND THEFT

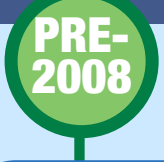

\section{THE BUILD-UP}

1999 - Aplitec (later NET1) purchased CPS from FNB.

At the time, CPS was

paying grants to $1.2 \mathrm{~m}$

people in South Africa

\& Namibia.

2003 - Limpopo Tender

Board irregularly awards

contract to CPS.

2006 -When SASSA

is established, NET1 start

to implement a strategy

of setting up infrastructure

to further access the grant

beneficiary target market

to push its financial

service offerings.

To do this, NET1 purchases

Moneyline (Pty) Lto

(which later establishes

EasyPay Everywhere

banking service).
SASSA CEO, Fezile Makiwane

concludes Letter of Agreement with SAPO.

Z

Zuma becomes President. Appoints

Edna Molewa as Minister of Social

Development (DSD) \& Bathabile

Dlamini as Deputy.

1

Makiwane is suspended based

on suspect 'report'.

Makiwane dismissed.

He later sues for defamation \&

gets R6m+ payout.

\section{$1 \mathrm{~L}+\mathrm{t}$}

Coceko Pakade appointed acting CEO of SASSA.

\section{1.}

\section{Zuma appoints Bathabile Dlamini} Minister of DSD.
Appeal by SASSA upheld by

Supreme Court of Appeals (SCA), previous ruling in favour of CPS overturned.

I

Grant Tender \#2 is released just 1 month after SCA ruling.

Virginia Peterson appointed CEO of SASSA.

1 II

Peterson issues Grant Tender \#2 bidders notice - changes biometric verification from "PREFERRED" to "MUST" ensuring CPS is the only valid contender.

1011 Grant Tender \#2 bids received.
Grant Tender \#2 awarded to CPS -

Hulley, Monyeki \& Moyane involved in bid evaluation \& adjudication process.

SASSA concludes contract with CPS.

Coceko Pakade becomes acting DG of DSD - followed by Wiseman Magasela.

Dlamini appoints Ministerial Advisory Committee (MAC).

\section{Attempted bribe}

Grant Tender \#1 cancelled alleged attempted bribe of Bid Adjudication Committee (BAC) chair by CPS.

CPS wins high court case against SASSA \& SAPO agreement, \& SASSA decision to enter into agreement is set aside - SASSA cannot contract SAPO.
CPS enters into MoA with Born Free Investments (BFI) \& other dodgy BEE companies for SASSA bid.

Black Sash Community Monitoring \& Advocacy Project (CMAP) begins to uncover violations of norms \& standards at pay points \& irregular/ unauthorised 3rd-party deductions from beneficiaries.

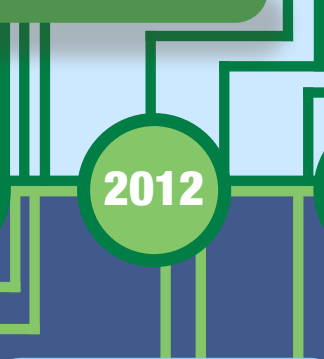

AlIPay \& other bidders take CPS to court.

NET1 enters new (separate) BEE deals with Business Venture Investments (BVI) \& others - links to power elite \& shadow state.

High court declares CPS/SASSA tender agreement process unlawful.

\section{PHASE \#1: SECURE MONOPOLY ON GRANT BENEFICIARY TARGET MARKET} re-registration of beneficiaries. Coincides with NET1 BVI BEE deal payout of same amount soon after. 


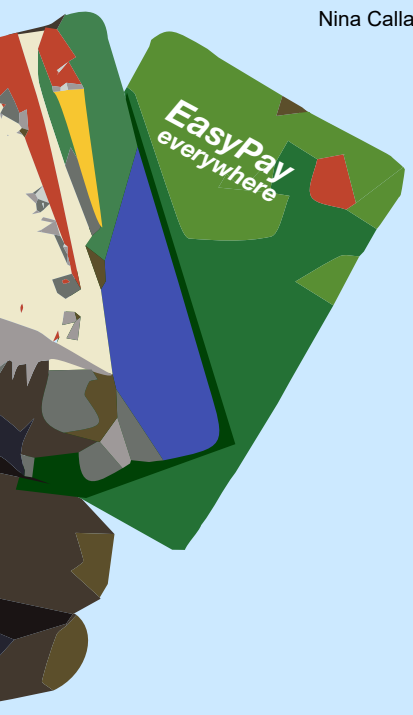

Grant Tender \#3 - SASSA initiates bidding process for grant payment services in line with ConCourt ruling.

MAC recommends SASSA builds its own payment system.

Thokozani Magwaza made acting DG of DSD.

\section{(1)}

Grant Tender \#3 released -

'engineered to fail'. CPS does not bid.

11 10

Dlamini instructs Petersen to

appoint work streams.

$1 \mathrm{r}$

I

Grant Tender \#3 adjudicated, not awarded due to "non-responsive bids".

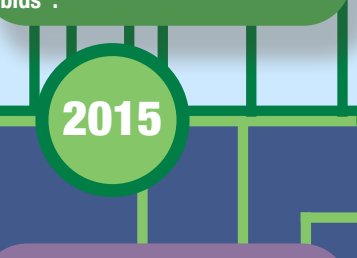

BEE PAYOUT

NET1 repurchases shares to repay BEE loan agreement.

Black Sash join AllPay court case - ConCourt rules new Request For Proposal (RFP) must have timeframes for new tender process.

NET1 launches EasyPay

Everywhere (EPE) bank accounts.

EPE bank accounts reach $600 \mathrm{~K}$.
SASSA-

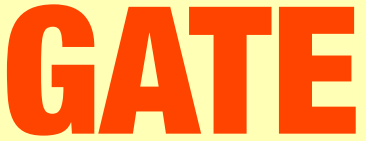

SASSA/DSD report to ConCourt that no contract is awarded \& promises to take over payments on 1 April 2017.

SASSA unable to take over grant payments in April 2017 (at this stage, unclear what they have done to take over payments) Legal Opinion \#1.

L

Virginia Petersen leaves office \& Raphaahle Ramokgopa appointed Acting CEO.

\section{口}

Work streams are irregularly appointed.

Thapoini

Thokozani Magwaza appointed CE0, Zane Dangor appointed DG of DSD.

\section{L}

Work streams issue first draft report - confirms SASSA unable to take over grants on time. Work streams want new SASSA contract with CPS - Legal Opinion \#2.

D

Technical Task Team (TIT) develops 6 options for SASSA to pay grants - Legal Opinion \#3.

Dram Dlamini is critical of TTT options, particularly against using banks.

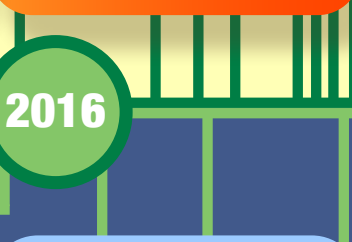

National Consumer Tribunal (NCT) rules there were good reasons to investigate Moneyline Moneyline appeals this ruling.

DSD amends regulations to limit deductions. Grindrod \& others approach High Court for clarity on illegal deductions.

EPE grows to over 1.1 million bank accounts.

Black Sash organise mass action held in CT, JHB \& DBN.
Af of State Capture, Stellenbosch: Afric

to extend CPS contract - all 3

Legal Opinions indicate SASSA

must approach ConCourt first.

Dlamini meets Zuma over

weekend, decides not to approach ConCourt.

\section{1}

Magwaza goes on sick leave, Dangor resigns from DG of DSD - Magasela is the acting CEO when SASSA negotiates (irregular) new contract with CPS.

\section{1}

Black Sash approaches ConCourt to intervene - ConCourt rule 1 year extension of invalid 2012 contract.

$$
\text { 1 } 1
$$

Zuma reshuffiles cabinet, leaving Dlamini in place \& fires Finance Minister Pravin Gordhan \& deputy Mcebisi Jonas.

\section{1 1}

Magwaza cancels work stream contracts with $\mathrm{R} 45 \mathrm{~m}$ already spent. Signs agreement with SAPO on taking over payment of grants.

Magwaza resigns \& Pearl Bhengu appointed acting CEO.

\section{Tra}

Magwaza with Dangor files affidavit with ConCourt responding to claims by Dlamini that she should not be held personally liable.

\section{H1 10 10 10}

National Treasury reports irregular SASSA/SAPO negotiations. InterMinisterial Committee intervenes \& SASSA \& SAPO sign agreement.

\section{1 1}

Bhengu signs off alleged irregular payments - coinciding with ANC national conference.

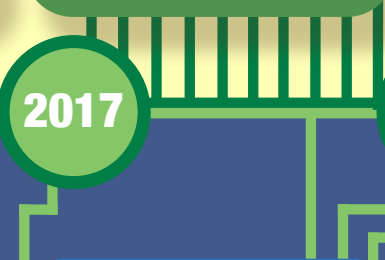

EPE has more than 2 million active bank accounts.

Black Sash organise mass action held in CT, JHB \& DBN.

Moneyline (EPE) oppose application by National Credit Regulator (NCR) to cancel its registration for alleged reckless lending to beneficiaries.

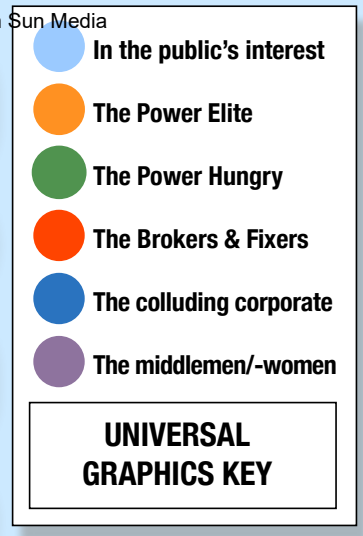

Enquiry into Dlamini's liability begins on 22 Jan.

\section{.}

Cyril Ramaphosa becomes President of SA, replaces Dlamini with Susan Shabangu as Minister of DSD.

$$
\text { DS. }
$$

Tender process initiated by Dlamini to replace CPS is cancelled \& cash payments added to SAPO contract.

$$
11
$$

ConCourt allows partial extension of CPS contract for 6 months

\& Corruption Watch wins case against CPS (R316m for irregular payment of re-registrations).

$$
\text { 1 } 11
$$

SASSA takes over direct payment to beneficiaries' individual bank accounts but battles to transfer EPE accounts to SAPO system.

Ahraham Mahlangu appointed acting CEO of SASSA.

I I I I I

Constitutional Court rules Dlamini to pay $\mathbf{2 0} \%$ of legal costs.

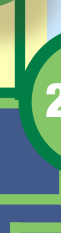

2018

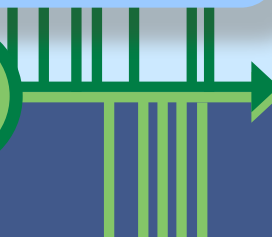

Over 2.4 million grant recipients who were transferred onto EPE are charged R10 account fees by Grindrod (to cover R9.50 NET1 service fee).

Report alleging CPS sabotaged SASSA/SAP0 efforts to transfer onto new system - filed with ConCourt.

SCA rules NET1 case against Social Assistance regulations moot highlights the ring-fenced SDA of the SAPO system.

SASSA institutes legal proceedings against Grindrod.

SASSA contract with CPS ends. 


\subsubsection{The Shape of State Capture}

The case study on the capture of SASSA illustrates several aspects of the state capture modus operandi which were identified in the Introduction. First is the securing of control over the public service, in particular through the appointment of Cabinet Ministers. Initially Zuma appointed Edna Molewa as the Minister of DSD in 2009, however, she was later relocated to the Department of Environmental Affairs and was replaced by her Deputy Minister Bathabile Dlamini in 2010.

The second component entails the intentional weakening of key technical institutions and formal executive processes. This is often achieved by 'removing' key top officials (such as Fezile Makiwane and Zane Dangor) and replacing them with people that would not be obstructionist; having officials only in acting positions (limiting ability to take long-term strategic decisions) as was the case in early 2016 where both the CEO and DG of DSD were acting appointments; and having persons who appear to be part of the shadow state, such as Michael Hulley and Patrick Monyeki, involved in the procurement process (both in 2012 and again in 2017). Also worth noting is the appointment of the work streams in 2016 and the instruction from Dlamini not to interfere, limiting the ability of the agency officials to carry out their mandate.

The third element of the state capture modus operandi entails securing access to opportunities for repurposing state institutions by manipulating or changing the directives or objectives of government. In this case in particular, it involved the manipulation of tender processes that resulted in the contract between SASSA and CPS for the nationwide payment of social grants. This was achieved by changing just one word in the tender specifications, where 'preferred' changing to 'must' changed the rules of the game.

In cases where the shadow state objectives are for accruing wealth, this type of manipulation of the procurement processes often centres around large-scale projects/ contracts. The original 2012 tender for the payments of social grants was worth an estimated R10bn and was the largest contract of its kind at the time. There is also often an element of 'scope creep' in the contracts, where the value is increased or the contract is extended, potentially indefinitely. CPS's windfall, which serendipitously coincided with their BEE partnership paying out, was as a result of an irregular extension for the 're-registration of grant beneficiaries', at an additional cost of R316m. Additionally, there were the seemingly deliberate delays which led to the Constitutional Court having to extend the invalid contract in March 2017 and again in 2018.

The last aspect of state capture that takes place both within and outside of government, is the creation of parallel political, governmental, and decision-making structures 
that undermine the functional operation of government institutions. In the SASSA case, it was the establishment of a parallel governance structure, where the recommendations of an external advisory team (the work streams which reported directly to the minister) were elevated above those of SASSA officials. There are also several accounts of unofficial meetings taking place, in various informal locations such as at the Minister's home and Nkandla, meetings with Michael Hulley (advisor and lawyer to Zuma) also play a key role in this aspect.

There are several other aspects of the state capture project that are worth reflecting upon, such as the organisational 'structure' of the shadow state and the roles which are filled by various members of the power elite. Bathabile Dlamini would be considered the "elite" due to her position as Minister of DSD and as President of ANCWL. Michael Hulley (Zuma's former lawyer), who played an active role in providing 'legal opinion' both in the awarding of the 2012 CPS contract and the 2017 SASSA-Gate crisis, could then be considered a "fixer". The fixer creates an accountability buffer between the elite and any illicit activities which are taking place within government. For example, Dlamini did not directly interfere in the Bid Evaluation, however, Michael Hulley and Patrick Monyeki (whose company would later be appointed as lead for the technical work stream) are alleged to have played a critical role ensuring that the Bidders Notice 2 change in biometric verification yielded the desired outcome the appointment of CPS. Lunga Ncwana could be considered the "broker", due to his personal and business relationship links to Dlamini and Hulley (in government), and with multiple individuals that were involved with the BEE partnerships/deals with Net1. Without having any direct involvement in any of the formal contracting, the broker is free to interact with and between both parties.

\subsubsection{The Underlying Politics}

To highlight the importance of the role that political power dynamics play in terms of how the state is governed, one need look no further than the trading of political favours (patronage) between Bathabile Dlamini and Zuma-centred elites. Dlamini was a crucial political supporter of Zuma in the lead up to the ANC Polokwane Conference, where in her position as Secretary-General she was able to mobilise significant support resulting in Zuma being nominated for President by the ANCWL. For this support, Dlamini was rewarded with the position of Deputy Minister (and later Minister) of the Department of Social Development. Then in 2015, her political status was elevated, allegedly through the support of the 'Premier League', to become President of the ANCWL. 


\section{SASSA-GATE When power \& greed cross paths}

\section{THE OWE WORD THAT GHANGED THE GAME}

2011 Jun - The grant payment Request For Proposal (RFP) is altered with Bidders Notice \#2. Bid specification for biometric verification is changed from "preferred" to "must", ensuring CPS is the only contender.
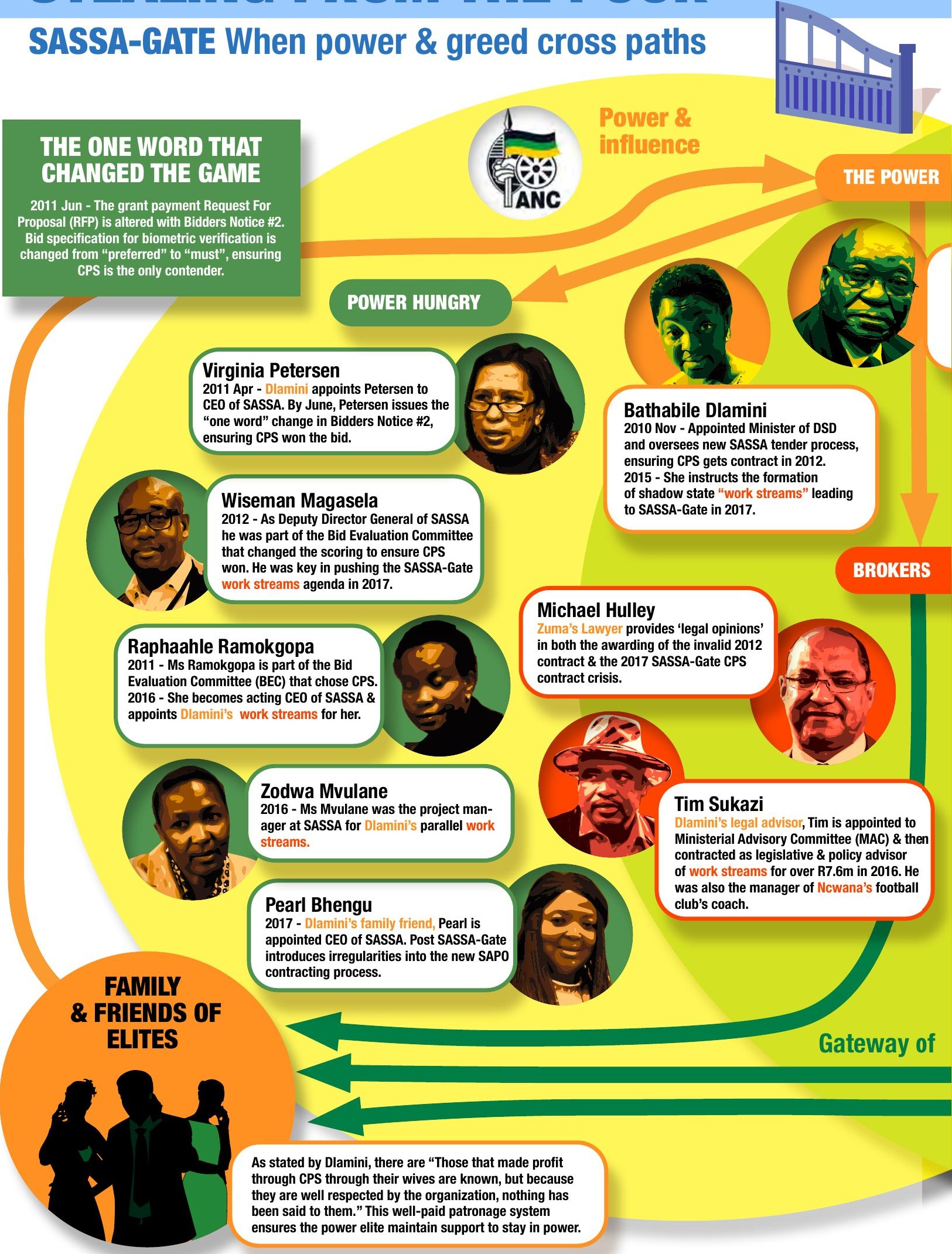

THE POWER

2011 Apr - Dlamini appoints Petersen to CEO of SASSA. By June, Petersen issues the s Notice \#2,

Wiseman Magasela

016 - Ms Mvulane was the project manager at SASSA for Dlamini's parallel work

\section{Pearl Bhengu} introduces irregularities into the new SAPO .

\section{Michael Hulley} contract crisis. ive \& policy adviso was also the manager of Ncwana's footbal club's coach. 
The political power Bathabile Dlamini wields in the governing party has undoubtedly protected her from having to account for her potentially corrupt (alternatively extreme incompetence) actions which lead to the SASSA-Gate debacle. This is evident by the fact that despite the scathing Constitutional Court judgment against Dlamini in mid March 2017, Zuma did not remove her from the position of Minister of DSD in the last cabinet reshuffle of his Presidency in late March 2017. Instead, Zuma removed a comparatively competent and effective minister of finance (Pravin Gordhan), without any rational motivation given to the public. This act showed to the country that the decisions Zuma was making as President were not in the interest of the country and were motivated by selective interests.

The political dynamics of the country, such as they are, means that Dlamini is still seemingly protected by the political position/power she retains as President of the ANCWL. This is evident from the fact that President Ramaphosa (with marginal National ANC Conference victory), though removing her from position of Minister of DSD, did not remove her from cabinet (transferring her to Minister of Woman under the Presidency).

By providing a brief summary of the finding of the Public Protector's investigation into the use of state resources for party political benefits, the case study also highlights just one of the many other ways in which the state can be repurposed under the project of state capture. In this case it is to reinforce voter support, by maintaining and reaffirming the association of delivery of public services with the governing political party.

\subsubsection{How Net1 Repurposed a Function of State}

No party has any claim to profit from the threatened invasion of people's rights. (Constitutional Court of South Africa, 2017b, p. 28)

This was potentially one of the most damning statements levelled against CPS in the March 2017 Constitutional Court judgment.

Over and above the irregular contracts, it would appear that the actual benefit that Net1 derived was as an indirect result of its appointment to pay grants, primarily from the sale of secondary financial services to grant beneficiaries. The problem here is not the pursuit of profit, but rather how the interests of this private company became the interest of certain state institutions. A lucrative state contract was used by the company to gain preferential access to a market consisting of poor and vulnerable people.

The history of CPS and Net1 goes back to the 1990s. Net1 UEPS Technologies Inc. was incorporated in Florida in May 1997 and later listed on the Nasdaq Stock Market 
in 2005. Over the years it expanded its interests across the world and is now the parent company of a range of subsidiaries that provide a variety of payment technology solutions and financial services, including CPS. In 2004, the company acquired a South African company, Net1 Applied Technology Holdings Ltd (or Aplitec), which was a public company listed on the Johannesburg Stock Exchange (JSE). It was in fact Aplitec (a smart card company, whose founder and CEO was Serge Belamant) that had initially bought CPS from First National Bank (FNB). At the time (1999), CPS had contracts to distribute grants to some 1.2 million people in South Africa and Namibia worth R54m (ITWeb, 1999). In the years that followed, Aplitec would go on to acquire Moneyline (Pty) Ltd and New World Finance (Pty) Ltd (both microlending businesses) (Net1, 2006) and later in 2006 Prism Holdings Ltd, which focused on "secure transaction technology, solutions and services", which later became the owner of EasyPay Ltd (Net1, 2008). These businesses would be central to Net1's overall business strategy, conceived back in 2006 .

The supply of secondary financial services has always been part of the business strategy and Net 1 publicly outlined how it would repurpose the state function, from as far back as 2006 (Net1, 2006) and 2008 (Net1, 2008, p. 6) Annual Reports. After being awarded the 2012 contract for the payment of grants by SASSA, and having undertaken the 're-registration' of all grant beneficiaries and recipients, in 2013, Net1 synthesised its strategy to a "first wave/second wave" approach, which is described in its annual reports as follows:

We use what we refer to as a "first wave/second wave" approach to market expansion. In the "first wave," we seek to identify an application for which there is a demonstrated and immediate need in a particular territory and then sell and implement our technology to fulfill this initial need. As a result, we should achieve the deployment of the required technological infrastructure as well as the registration of a critical mass of cardholders or customers. During this phase, we should generate revenues from the sale of our software and hardware devices, as well as ongoing revenues from transaction fees, maintenance services and the use of our biometric verification engine. Once the infrastructure has been deployed and we achieve a critical mass of customers, we intend to focus on the "second wave," which should allow us to use this infrastructure to provide users, at a low incremental cost to us, with a wide array of financial products and services for which we can charge fees based on the value of the transactions performed. (Net1, 2013)

What is important to highlight is that this business strategy has long been known to veteran DSD officials, such as Zane Dangor, who led the negotiations with the various service providers in 2008/2009 (Dangor, 2017b). It is a practice that has been frowned upon by those who understood the potential negative ramifications that could result 
from allowing a company that pays grants to also sell secondary financial services to beneficiaries. The 2012 contract between SASSA and CPS stated that the "Contractor [CPS] shall not use data belonging to SASSA for any purpose other than for the performance of the services" (McKune, 2017). Even though over the years SASSA had threatened to cancel its contract with CPS, it would seem the restriction on the use of beneficiary data was never properly enforced. As a result, Net1 was able to move directly from establishing access to the market to pushing its proprietary financial services that had nothing to do with the service provided to the state. As highlighted in How One Word can Change the Game (Foley \& Swilling, 2018, p. 45):

\begin{abstract}
... the 'genius' of Net1 business model: it was paid [by the government and in turn taxpayers] to establish a massive client base and ensure the payment technology is adopted by the major commercial businesses involved; it then leveraged beneficiary data and information to which only it had access to sell financial products, knowing that there is minimal risk of non-payment.
\end{abstract}

The main allegation levied against Net1 concerns the use of grant recipients' personal information and data, held by CPS in terms of the payment services contract with SASSA. It is alleged that this information is exchanged between and within the Net1 group of companies. Particular focus has been placed on Moneyline, which provides microloans. By virtue of the fact that it has access to and knowledge of a beneficiary's income significantly reduces risk for the business, which means it has an unfair advantage over other competitors in the market. The second advantage derived is that the enrolment process of beneficiaries for these services is made both easier and cheaper for Net1 companies. The third allegation involves the use of beneficiaries' personal details, such as contact numbers, for marketing products and services ("ambush" marketing practices) (De Lange, 2017; ITWeb, 2017; Van Zyl, 2016; Mawson, 2015).

In order to counter the various allegations of Net1's inappropriate (possibly fraudulent) business practices, the company appointed auditing firm KPMG to conduct an investigation into its operations. The scope of the investigation was determined by Net1 and as such the investigation was limited in its finding and applicability, in terms of the actual accounts provided by beneficiaries and even Net1 employees (Black Sash, 2018; Foley \& Swilling, 2018; Torkelson, 2020). It became apparent that, through the ruling by the Constitutional Court and the ground swell of negative sentiment, it was unlikely CPS would continue payment of social grants beyond April 2018 (though this would only be final in September 2018). The Panel of Experts that were appointed by the Constitutional Court to oversee the transition reported allegations against Net1 (in partnership with Grindrod Bank) of intentionally attempting to sabotage the migration from CPS to SAPO. This sabotage entailed implementing a misinformation 
campaign to get grant recipients to open EasyPay Everywhere (EPE) bank accounts and not allowing SASSA and SAPO employees access to sites where grant recipients receive their cash payments (Auditor General, 2018).

\subsection{THE COST OF SASSA STATE CAPTURE}

For many people in this country the payment of social grants by the state provides the only hope of ever living in the material conditions that the Constitution's values of dignity, freedom and equality promise. About 15 million people depend on the payment of these social grants. They are vulnerable people, living at the margins of affluence in our society. (Constitutional Court of South Africa, 2013, p. 3)

In 1994, when the democratically elected ANC government was instituted, the social security system that was inherited was skewed towards favouring white pensioners, with little protections in place for addressing the plight of African women and children. The system was to be reformed to cater for all South African citizens equitably and fairly. Access to social security is one of several socio-economic rights guaranteed in the South African Constitution of 1996, where Section 27(1)(c) of the constitution states that "Everyone has the right to have access to ... social security, including, if they are unable to support themselves and their dependents, appropriate social assistance" (Republic of South Africa, 1996).

However, unlike other socio-economic rights, such as the right to freedom of expression or property rights, the Constitution also recognises and accommodates for the practical limitations on the government's ability to comprehensively fulfil this mandate, in that the government is subject to an internal limitation of the resources which are available. Section 27(2) in the constitution states that "The state must take reasonable legislative and other measures, within its available resources, to achieve the progressive realisation of each of these rights" (Republic of South Africa, 1996). This caveat is a necessity, in that it allows for flexibility in terms of establishing policy and the management of the state's budget and the country's fiscal sustainability. It is in this regard that the expansion and application of the social grants policy can arguably be viewed as one of the greatest post-1994 redistributive achievements.

Under the Mbeki Presidency, social grants were identified as a key component of the Growth, Employment and Redistribution (GEAR) framework, which was adopted. The increased scope of social grants was implemented as the main form of wealth redistribution and was the principle programme which sought to account for the flaws/shortcomings of implementing neo-liberal economic policies (Khan, 2013). As a result, there was a significant growth in the number of grant recipients, in particular the introduction of Child Support Grants in the early and mid 2000s which resulted 
in the number of South African citizens receiving social grants ballooning from approximately 3 million beneficiaries in 2000 (primarily old age grants) to over 12 million beneficiaries by 2008. As of December 2017, there were over 17 million grant beneficiaries.

Social grants are targeted at providing financial relief to the most vulnerable in South Africa's society, namely the elderly, children, persons with disabilities and temporary assistance for those experiencing financial hardship outside of their control. As Khan (2013, p. 575) highlights, social grants are no longer just a "stop-gap measure" for counter-balancing the deficiencies in the government's policies to achieve meaningful structural transformation of the economy, social grants "are now a structural necessity and 'politically irreversible pillars of social policy"'.

It is not possible to provide a comprehensive, all-encompassing estimation of the cost which can be attributed to the state capture of SASSA. There are in fact several costs which need to be considered and some are not definitely quantifiable, however, the following have been identified:

- Cost of the 2012 irregular contract (estimated R10bn over 5 years, as well as then the cost incurred to the state as a result of the contract extensions). Added to this should be the legal costs relating to the litigation of the contract.

- Opportunity cost to the state in that seven years after the SASSA/CPS contract was signed. We are back at a point where SASSA is contracting with SAPO for the payment of grants. The weakening of SASSA as an institution should also be taken into account. This is not something that cannot be readily quantified, however, with the recent appointment of SAPO it is evident that the appointment of CPS was arguably an unnecessary delay in grant payment being undertaken by government itself.

- There is the highly questionable escalation of irregular expenditure at the department from only R8.8m in 2007 to R1.4bn in 2017. Included in this amount are the irregular payments of R316m to CPS (for the 're-registration of beneficiaries') and $\mathrm{R} 43 \mathrm{~m}$ paid to the work streams.

- Of course, there is the slow repressiveness of the value of grants themselves (where annual grants are increased at CPI, which is lower than real food inflation), the $1 \%$ increase to VAT, numerous fuel increases, etc. Even though this cannot be attributed directly to the capture of SASSA, this is the result of the fiscal and economic impacts/decisions of the Zuma administration.

- The most important is the costs to beneficiaries. There are not definitive figures for this as yet, but it is known that beneficiaries did incur potentially unnecessary costs relating to transactions fees by CPS/Grindrod. Then there are the monies 
lost which correspond with the 'illegal'/immoral deductions from grants (May 2016, Magwaza reported that at that stage "the total monetary loss due to the unlawful deductions was close to R800 million").

\subsection{CONCLUSION: THE CONSTITUTIONAL STATE AT WORK}

The capture of SASSA was not just a form of "grand corruption" resulting in a financial loss to the state and taxpayer, but was a political project that has had a direct negative impact on the poorest and most vulnerable in our society; the consequences of which will undoubtedly be felt for years to come. Though the case study does not present a smoking gun, in terms of corruption or state looting, there are several questions raised in this regard and it is possible that grand-scale looting was actually prevented due to the interventions by AllPay, the Judiciary, civil society, and the media.

The significant role civil society groups played, by approaching the Constitutional Court, needs to be acknowledged. Together with officials who spoke out, this configuration has made it possible to keep the grant payment system more or less on track to the benefit of millions. Had there been no intervention, a likely possible scenario would have been that CPS was awarded a new contract, thus making possible massive profits for a company and its associated networks off the backs of South Africa's poorest. Thankfully, this did not happen. This case study highlighted the various actors/institutions which play a crucial role in preventing the rules from being abandoned, defending the Constitution and throwing light on the shadows where the 'skeletons' hide. These are the unsung heroes who speak truth to power and give voice to South Africa's most vulnerable, in particular:

- The Judiciary, who time and again has been forced to walk the line of the separation of powers without crossing it, to ensure that recourse is found to address the failures of the Executive and ensure that those in power are at least held to account in terms of their legal obligations, even though they seem impervious to political rebuke. The order they made was seminal - without it 17 million South African citizens may not have received the grants on which they so desperately depend;

- The various NGOs and civil society advocacy groups, such as the Black Sash Trust, Centre for Applied Legal Studies and Corruption Watch, which have initiated litigation on behalf of the most vulnerable and actively partnered and supported the government in the development of progressive social policy;

- The committed civil servants and whistle-blowers who refused to pander to political pressure, dedicated themselves to serving in the interest of public good, and spoke out when they witnessed improper acts (or statements) by those in power; and 
- The investigative reporting by brave men and women in the news media, such as GroundUp, Business Day (Ann Crotty), Daily Maverick (Marianne Thamm) and amaBhungane (Craig McKune and Sam Sole), who ask the tough questions and expose the lies.

This case study serves to highlight that state capture extends beyond the narrow objective of extracting monetary wealth. The capture of SASSA demonstrates that state capture can actually result in the repurposing of a fundamental function of government itself. Here the constitutional obligation of the state - the administration of social grants - was handed to a private company, knowing that this function would be repurposed to enable said company to profit from the poor. 


\section{References}

Adjudication Committee (2008) Narrative Report of the Adjudication Committee for Tender: SASSA 19/06/BS, SASSA. Pretoria: South African Social Security Agency. [Online].https://bit.ly/3xr287P

Arendse, N. (2009) 'Statement of Adv. Norman Arendse, GroundUp. [Online]. https://bit.ly/ 3rZbUg4 (Accessed 27 September 2018).

Auditor General (2018) 'Black Sash Trust v Minister of Social Development and Others: Sixth report to the Constitutional Court by Auditor-General and Panel of Experts', Constitutional Court of South Africa. South Africa: Constitutional Court of South Africa.

Bainbridge, C.B. (2009) 'Statement of Colleen Beverley Bainbridge', Ground Up. [Online]. https://bit.ly/3jQ8EjN (Accessed 27 September 2018).

Bejoy, R. (2016) 'Corruption allegations against Gideon Sam come back to life', Ground Up. [Online].https://bit.ly/3Aq71j5 (Accessed 27 September 2018).

Black Sash (2018) Interview with Black Sash Management, 7 December.

Cabinet (2011) 'Statement on Cabinet meeting of 20 April 2011', GCIS. [Online]. https:// bit.ly/3fEtEZi (Accessed 23 August 2017).

Cape Times (2014) Sassa reviews system to pay out grants. [Online]. https://bit.ly/3s33X9C (Accessed 1 September 2018).

Chopra, D. (2015) News Release: Net 1 Reports Closure of Hawks Investigation in South Africa, Net1 UEPS Technologies Inc. Johannesburg. [Online]. https://bit.ly/ 3xrO2CV (Accessed 1 December 2017).

Constitutional Court of South Africa (2013) AllPay vs SASSA and CPS: [2013] ZACC 42 (29 November 2013) - Judgment (AllPay 1).

Constitutional Court of South Africa (2014) AllPay vs SASSA and CPS: [2014] ZACC 12 (17 April 2014) - Judgment (AllPay 2).

Constitutional Court of South Africa (2017a) Black Sash Trust v Minister of Social Development and Others: [2017] ZACC 20 (15 June 2017) - Judgment 2. [Online]. https://bit.ly/2X20o8h (Accessed 17 March 2019).
Constitutional Court of South Africa (2017b) Black Sash Trust v Minister of Social Development and Others: [2017] ZACC 8 (17 March 2017) - Judgment 1.

Constitutional Court of South Africa (2018a) Black Sash Trust $v$ Minister of Social Development and Others: CCT 48/17 (23 March 2018) - Order 3.

Constitutional Court of South Africa (2018b) Black Sash Trust $v$ Minister of Social Development and Others: ZACC 36 (27 September 2018) - Cost Order Dlamini.

Constitutional Court of South Africa (2018c) South Africa Social Security Agency and another v Minister of Social Development and others [2018] ZACC 26 (30 August 2018) - Black Sash Case Costs Order 1.

Dangor, Z. (2017a) 'Black Sash Trust v Minister of Social Development and Others: Dangor Affidavit 10 April 2017, Constitutional Court of South Africa.

Dangor, Z. (2017b) Interview with Zane Dangor, 24 October.

Dlamini, B. (2019) Bathabile Dlamini Resignation Letter to ANC. https://bit.ly/37oMuPI

Dzonzi, T. (2017) 'Sassa scraps Bathabile Dlamini's advisory teams', Fin24. South Africa. [Online].https://bit.ly/3ixZBoa (Accessed 1 December 2017).

Ensor, L. (2017) 'Bathabile Dlamini names Pearl Bhengu acting Sassa head', Business Day. [Online].https://bit.ly/3s1kOts (Accessed 1 December 2017).

Foley, R. \& Swilling, M. (2018) 'How One Word Can Change the Game: Case Study of State Capture and the South African Social Security Agency', State Capacity Research Project. [Online]. https://bit.ly/3CsR1yQ(Accessed 6 August 2018).

Herman, P. (2017) 'Sassa: Clock ticking for Post Office to deliver, says Scopa', News24. [Online].https://bit.ly/37prx7a (Accessed 23 November 2019).

Herman, P. (2018) 'Sassa cancels tender process to find CPS replacement', Mail \& Guardian. [Online]. https://bit.ly/3CtABpR (Accessed 12 June 2018). 
ITWeb (1999) Aplitec acquires FNB subsidiary. [Online].https://bit.ly/2VuqSiC (Accessed 1 December 2017).

ITWeb (2017) Court allows deductions on SASSA accounts. [Online]. https://bitly/ 2VFrpOp (Accessed 1 December 2017).

Khan, F. (2013) 'Poverty, grants, revolution and "real Utopias": society must be defended by any and all means necessary!', Review of African Political Economy, 40(138):572-588. https://doi.org/10.1080/03056244.20 13.854035

De Lange, I. (2017) 'Social grant deductions allowed, court rules', The Citizen. [Online]. https://bit.ly/2VyDAMO (Accessed 1 December 2017).

Mawson, N. (2015) Net 1 cleared of dodgy lending, ITWeb. [Online]. https://bit.ly/ 2VyQQBr (Accessed 1 December 2017).

McKune, C. (2012) "Name your Price' bribe offer for R7-billion tender', Mail \& Guardian. South Africa. [Online]. https://bit.ly/2VrzAhz (Accessed 27 September 2018).

McKune, C. (2017) 'Serge Belamant, Sassa and the 'war chest' of poor people', amaBhungane. [Online].https://bit.ly/3yAzh20 (Accessed 14 December 2017).

Net1 (2006) Net1 UEPS Technologies Inc. Annual Report-2006, Net1 UEPS Technologies Inc. [Online]. https://bit.ly/ 3lI4c8Z (Accessed 27 September 2018).

Net1 (2008) Net1 UEPS Technologies Inc. Annual Report-2008, Net1 UEPS Technologies Inc. [Online]. https://bit.ly/ 3lJXakm (Accessed 27 September 2018).

Net1 (2013) Net1 UEPS Technologies Inc. Annual Report-2013.

Quintal, G. (2019) 'Judge Nugent rules in Sassa’s favour in R1.3bn CPS claim', Mail \& Guardian. [Online]. https://bit.ly/3f Kh76B (Accessed 29 November 2019).

Republic of South Africa (1996) Constitution of the Republic of South Africa. Pretoria: Constitutional Assembly.

Republic of South Africa (1999) 'Public Finance Management Act [No. 1 of 1999] (PFMA)',
Government Gazette, No. 33059. Pretoria:

The Presidency. [Online]. https://bit.ly/ 3ywqHS3

Republic of South Africa (2004a) 'Social Assistance Act [No. 13 of 2004]', Government Gazette. Pretoria: The Presidency.

Republic of South Africa (2004b) 'South African Social Security Agency Act [No. 9 of 2004]', Government Gazette. Pretoria: The Presidency.

Saba, A. (2018) 'Bathabile Dlamini slapped with court costs, possible perjury probe', Mail \& Guardian. [Online]. https://bit.ly/3fLOZBR (Accessed 23 November 2019).

SABC Digital News (2017) 'SASSA ensures parliament it will pay social grant beneficiaries', YouTube. [Online]. https://bit.ly/3lF4UUE (Accessed 1 December 2017).

Sole, S. \& McKune, C. (2017) 'Social grants payment crisis - everything you need to know but were afraid to ask', amaBhungane. [Online]. https://bit.ly/3yA2rhP (Accessed 1 December 2017).

Supreme Court of Appeal of South Africa (2011) The Chief Executive Officer of the South African Social Security Agency v Cash Paymaster Services (Pty) Ltd: [2011] ZASCA 13, 11 March 2011.

Thamm, M. (2017a) 'SassaGate: As dark clouds gather, Bathabile Dlamini fires special adviser Sipho Shezi, Daily Maverick. South Africa. [Online].https://bit.ly/37qWub5 (Accessed 1 December 2017).

Thamm, M. (2017b) 'SassaGate Reloaded: Expert panel and $A G$ warn of serious risk in future social grant payments', Daily Maverick. [Online]. https://bit.ly/3jwLnTO (Accessed 1 December 2017).

Torkelson, E. (2020) 'Collateral damages: Cash transfer and debt transfer in South Africa', World Development, 126(C). https:// doi. org/10.1016/j.worlddev.2019.104711

United States Department of Justice (U.S. DoJ) (2017) 'United States Department of Justice letter to Net 1', Net1 UEPS Technologies Inc. Washington, D.C.: United States Department of Justice. [Online]. https://bit.ly/3xw83IA 
United States Securities and Exchange Commission (U.S. SEC) (2015) 'U.S. SEC Letter May 29 2015; Net1 UEPS Technologies Inc. Washington, D.C.: United States Securities and Exchange Commission. [Online]. https://bit.ly/2U2xggd
Van Zyl, G. (2016) 'New social grant regulations face court challenge', Fin24. [Online].https://bit.ly/3rZauCu (Accessed 1 December 2017). 



\section{APPENDIX}

\begin{tabular}{|c|c|c|c|c|}
\hline $\begin{array}{l}\text { Case Study } \\
\text { in State } \\
\text { Capture }\end{array}$ & Status & Summary Description & $\begin{array}{l}\text { Investigation } \\
\text { Body / } \\
\text { Source of } \\
\text { Evidence }\end{array}$ & $\begin{array}{l}\text { Government } \\
\text { Entity } \\
\text { Implicated }\end{array}$ \\
\hline \multicolumn{5}{|c|}{ Scandals Connected to Jacob Zuma, Guptas, Other Key Networks and ANC Politics } \\
\hline $\begin{array}{l}\text { The State } \\
\text { of Capture } \\
\text { report - } \\
\text { focuses } \\
\text { on Guptas' } \\
\text { relationship } \\
\text { with Jacob } \\
\text { Zuma and } \\
\text { their alleged } \\
\text { influence on } \\
\text { the affairs } \\
\text { of state }\end{array}$ & $\begin{array}{l}\text { First complaint } \\
\text { was received } \\
\text { in March } 2016 \\
\text { and the report } \\
\text { was released in } \\
\text { November } 2016 .\end{array}$ & $\begin{array}{l}\text { Investigation into complaints of alleged improper } \\
\text { and unethical conduct by the President and } \\
\text { other State Functionaries, relating to alleged } \\
\text { improper relationships and involvement of the } \\
\text { Gupta Family in the removal and appointment } \\
\text { of Ministers and Directors of State-Owned } \\
\text { Enterprises (SOEs), resulting in improper and } \\
\text { possibly corrupt award of State Contracts and } \\
\text { Benefits to the Gupta Family's Businesses. } \\
\text { The report details numerous allegations of } \\
\text { the Guptas' involvement in affairs of the state } \\
\text { and their irregular activities that enable rent } \\
\text { extraction. The findings were not conclusive } \\
\text { and the remedial action was to establish a } \\
\text { commission of inquiry into state capture (to } \\
\text { be appointed by the President, but with a } \\
\text { judge selected by the Chief Justice). Litigation } \\
\text { endeavoured to delay or prohibit the report's } \\
\text { release and implementation of remedial actions, } \\
\text { but failed, and the commission was established } \\
\text { in } 2018 \text {. }\end{array}$ & $\begin{array}{l}\text { - Public } \\
\text { Protector, } \\
\text { followed by } \\
\text { litigation }\end{array}$ & $\begin{array}{l}\text { - GCIS (The } \\
\text { New Age) } \\
\text { - Eskom } \\
\text { (Optimum) } \\
\text { - Transnet } \\
\text { (Regiments/ } \\
\text { Trillian) } \\
\text { - Denel } \\
\text { - SAA (The } \\
\text { New Age) } \\
\text { - SABC (The } \\
\text { New Age) } \\
\text { - Department of } \\
\text { Finance } \\
\text { - Transport } \\
\text { (SAA) } \\
\text { - Communica- } \\
\text { tions (SABC } \\
\text { \& GCIS) }\end{array}$ \\
\hline $\begin{array}{l}\text { Zondo } \\
\text { Commission }\end{array}$ & $\begin{array}{l}\text { Established } \\
\text { in 2018, with } \\
\text { anticipated } \\
\text { conclusion being } \\
\text { the end of } 2021 .\end{array}$ & $\begin{array}{l}\text { Formally titled the Judicial Commission of } \\
\text { Inquiry into Allegations of State Capture, } \\
\text { Corruption and Fraud in the Public Sector } \\
\text { including Organs of State, the Commission } \\
\text { was promulgated by then President Zuma in } \\
\text { response to the remedial actions as outlined in } \\
\text { the Public Protector's State of Capture report. } \\
\text { As of June } 2021 \text {, the Commission that started } \\
\text { in August } 2018 \text { has held more than } 418 \text { days } \\
\text { of hearings of over } 330 \text { testimonies (generating } \\
\text { over } 71000 \text { pages of transcript). The inquiry's } \\
\text { terms of reference were expansive and, as } \\
\text { such, the scope of investigations went beyond } \\
\text { merely looking into the Gupta-related cases, } \\
\text { covering other networks (e.g., Bosasa) as well } \\
\text { as other government institutions (e.g., role } \\
\text { of Parliament). }\end{array}$ & $\begin{array}{l}\text { - Zondo } \\
\text { Commission }\end{array}$ & $\begin{array}{l}\text { Various } \\
\text { work-streams } \\
\text { covering } \\
\text { inter alia: } \\
\text { - SOEs } \\
\text { (Eskom, } \\
\text { Transnet, } \\
\text { Denel, SAA) } \\
\text { - Free State } \\
\quad \text { Provincial } \\
\text { Government } \\
\text { - Bosasa } \\
\text { - SARS } \\
\text { - Law } \\
\text { enforcement } \\
\text { - State Security } \\
\text { Agency (SSA) } \\
\text { - The New Age } \\
\text { \& ANN7 } \\
\text { - Role of } \\
\text { Parliament } \\
\text { and ANC }\end{array}$ \\
\hline
\end{tabular}




\begin{tabular}{|c|c|c|c|c|}
\hline $\begin{array}{l}\text { Case Study } \\
\text { in State } \\
\text { Capture }\end{array}$ & Status & Summary Description & $\begin{array}{l}\text { Investigation } \\
\text { Body / } \\
\text { Source of } \\
\text { Evidence }\end{array}$ & $\begin{array}{l}\text { Government } \\
\text { Entity } \\
\text { Implicated }\end{array}$ \\
\hline \multicolumn{5}{|c|}{ Scandals Connected to Jacob Zuma, Guptas, Other Key Networks and ANC Politics } \\
\hline Bosasa & $\begin{array}{l}\text { Dating back to a } \\
2009 \text { SIU report. } \\
\text { Investigations and } \\
\text { various litigations } \\
\text { are ongoing. }\end{array}$ & $\begin{array}{l}\text { In 2019, former Bosasa C00, Anglo Agrizzi, } \\
\text { testified at the Zondo Commission, detailing } \\
\text { the acts and long history of corruption between } \\
\text { various Bosasa companies predominantly } \\
\text { owned by Gavin Watson, and numerous } \\
\text { government entities/departments. The } \\
\text { testimony of Agrizzi (and other former Bosasa } \\
\text { employees) corroborated the findings of a } \\
2009 \text { SIU investigation that alleged corruption } \\
\text { in several contracts Bosasa had with the } \\
\text { Department of Correctional Services. Criminal } \\
\text { court proceedings have been initiated based } \\
\text { on the } 2009 \text { SIU investigation, along with new } \\
\text { investigations initiated by SARS and other law } \\
\text { enforcement entities. }\end{array}$ & $\begin{array}{l}\text { - Special } \\
\text { Investi- } \\
\text { gation } \\
\text { Unit (SIU) } \\
\text { - Zondo } \\
\text { Commission }\end{array}$ & $\begin{array}{l}\text { - Department of } \\
\text { Correctional } \\
\text { Services } \\
\text { - Department of } \\
\text { Justice } \\
\text { - Department of } \\
\text { Home Affairs } \\
\text { - Department of } \\
\text { Transport } \\
\text { - Various SOEs } \\
\text { (e.g., SAPO, } \\
\text { ACSA) } \\
\text { - National } \\
\text { Prosecuting } \\
\text { Authority } \\
\text { (NPA) } \\
\text { - Members of } \\
\text { Parliament }\end{array}$ \\
\hline Arms Deal & $\begin{array}{l}\text { Various } \\
\text { investigations and } \\
\text { sources, dating } \\
\text { back to 1990s. } \\
\text { Most significant } \\
\text { source being } \\
\text { through Seriti } \\
\text { Commission. } \\
\text { Corruption case } \\
\text { against Zuma is } \\
\text { ongoing. }\end{array}$ & $\begin{array}{l}\text { Commission of Inquiry into allegations of fraud, } \\
\text { corruption, impropriety, or irregularity in the } \\
\text { Strategic Defence Procurement Packages } \\
\text { (SDPP). Various court cases related to } \\
\text { allegations of corruption against Jacob Zuma. } \\
\text { On Monday, } 24 \text { October 2011, the President } \\
\text { announced the Commission chaired by Judge } \\
\text { Seriti. The findings of the Commission were that } \\
\text { there was "no evidence" of corruption, but this } \\
\text { is seen by many to have been a whitewash. The } \\
\text { report was taken on review and set aside in } \\
\text { August } 2019 \text {. The corruption case against Zuma } \\
\text { is ongoing before the courts. }\end{array}$ & $\begin{array}{l}\text { - Seriti } \\
\text { Commission } \\
\text { - Various } \\
\text { court cases }\end{array}$ & $\begin{array}{l}\text { Initially: } \\
\text { - South African } \\
\text { National } \\
\text { Defence } \\
\text { Force } \\
\text { - Members of } \\
\text { Parliament } \\
\text { Allegations also } \\
\text { involve: } \\
\text { - NPA } \\
\text { - SSA }\end{array}$ \\
\hline $\begin{array}{l}\text { Nkandla } \\
\text { Security } \\
\text { Upgrades }\end{array}$ & $\begin{array}{l}\text { Investigation } \\
\text { started in } \\
\text { November } 2012 . \\
\text { Report on } \\
\text { investigation } \\
\text { was released in } \\
\text { March } 2014 .\end{array}$ & $\begin{array}{l}\text { Report on security upgrades to President } \\
\text { Zuma's homestead in Nkandla. The investigation } \\
\text { found that the President unduly benefited from } \\
\text { the upgrades and as part of remedial actions } \\
\text { the President was required to pay back a portion } \\
\text { of the costs of the upgrades. Zuma instructed } \\
\text { that SAPS undertake their own investigation, } \\
\text { which sought to rationalise the expenses (fire- } \\
\text { pool report). Parliament accepted this alternative } \\
\text { report, but major court cases followed, } \\
\text { ultimately declaring that the Public Protector's } \\
\text { remedial actions are binding. President and } \\
\text { Parliament failed to uphold the Constitution. } \\
\text { President ordered to "pay back the money". }\end{array}$ & $\begin{array}{l}\text { - Public } \\
\text { Protector's } \\
\text { Secured } \\
\text { in Comfort } \\
\text { report, } \\
\text { followed by } \\
\text { litigation }\end{array}$ & 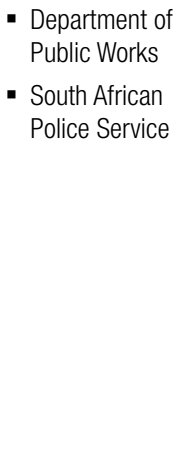 \\
\hline
\end{tabular}




\begin{tabular}{|c|c|c|c|c|}
\hline $\begin{array}{l}\text { Case Study } \\
\text { in State } \\
\text { Capture }\end{array}$ & Status & Summary Description & $\begin{array}{l}\text { Investigation } \\
\text { Body / } \\
\text { Source of } \\
\text { Evidence }\end{array}$ & $\begin{array}{l}\text { Government } \\
\text { Entity } \\
\text { Implicated }\end{array}$ \\
\hline \multicolumn{5}{|c|}{ Scandals Connected to Jacob Zuma, Guptas, Other Key Networks and ANC Politics } \\
\hline $\begin{array}{l}\text { Private } \\
\text { Aircraft } \\
\text { Landing at } \\
\text { Waterkloof } \\
\text { Airforce Base } \\
\text { and Gupta } \\
\text { Sun City } \\
\text { Wedding }\end{array}$ & May 2013. & $\begin{array}{l}\text { In 2013, justice, crime prevention, and } \\
\text { security cluster (JCPS) - a cabinet structure } \\
\text { composed of various ministries - undertook an } \\
\text { investigation into the Landing of a Commercial } \\
\text { aircraft at Air Force Base Waterkloof (report } \\
\text { titled the same). The investigation revealed that } \\
\text { the Guptas initially tried to organise a special } \\
\text { landing at OR Tambo International Airport, but } \\
\text { was turned down. They then approached the } \\
\text { Indian High Commission who re-designated the } \\
\text { wedding entourage as an official delegation to } \\
\text { secure a landing at the Waterkloof base. The } \\
\text { wedding held at Sun City was attended by a } \\
\text { number of high-profile ANC politicians and was } \\
\text { paid for in part by moneys looted from the Vrede } \\
\text { Dairy Farm project. }\end{array}$ & $\begin{array}{l}\text { - Report by } \\
\text { JPCS } \\
\text { - Zondo } \\
\text { Commission }\end{array}$ & $\begin{array}{l}\text { - Department of } \\
\text { International } \\
\text { Relations and } \\
\text { Cooperation } \\
\text { (DIRCO) } \\
\text { - Department of } \\
\text { Defence } \\
\text { - Department of } \\
\text { Transport }\end{array}$ \\
\hline $\begin{array}{l}\text { Free State } \\
\text { Provincial } \\
\text { Capture, } \\
\text { includes } \\
\text { Vrede Dairy } \\
\text { Farm and } \\
\text { Asbestos } \\
\text { Contracts }\end{array}$ & Ongoing. & $\begin{array}{l}\text { The Vrede Dairy Farm project was initiated } \\
\text { by the Free State Provincial Government as a } \\
\text { development project, however, in partnering with } \\
\text { a Gupta-linked company Estina, government } \\
\text { funds were looted. In 2018, the Public } \\
\text { Protector released a report on their } 2018 \\
\text { investigation, but it was taken on review and } \\
\text { set aside by the courts. The second part of the } \\
\text { investigation is yet to be finalised. The NPA } \\
\text { laid criminal charges against Gupta associates } \\
\text { and implicated government officials. Court } \\
\text { proceedings are ongoing. } \\
\text { Significant testimony and evidence have been } \\
\text { presented at the Zondo Commission regarding } \\
\text { the Vrede Farm case, as well as the asbestos } \\
\text { inspection project (criminal proceedings are also } \\
\text { underway). Both projects implicate high-profile } \\
\text { politicians and senior officials manipulating } \\
\text { government process. }\end{array}$ & $\begin{array}{l}\text { - } \text { Public } \\
\text { Protector } \\
\text { reports } \\
\text { - Zondo } \\
\text { Commission } \\
\text { - Various } \\
\text { court cases }\end{array}$ & $\begin{array}{l}\text { - Free State } \\
\text { Provincial } \\
\text { Government }\end{array}$ \\
\hline $\begin{array}{l}\text { Irregular } \\
\text { removal of } \\
\text { National } \\
\text { Director } \\
\text { of Public } \\
\text { Prosecutions } \\
\text { (NDPP), } \\
\text { Mxolisi } \\
\text { Nxasana }\end{array}$ & $\begin{array}{l}\text { Inquiry instituted } \\
\text { in February } 2015, \\
\text { but was cancelled } \\
\text { in May } 2015 . \\
\text { This triggers the } \\
\text { Constitutional Court } \\
\text { cases that followed. }\end{array}$ & $\begin{array}{l}\text { Inquiry into the fitness of Mxolisi Nxasana to } \\
\text { hold office as NDPP. The Inquiry was cancelled } \\
\text { after Zuma "agreed to let Nxasana resign". He } \\
\text { was paid R17m - the balance of his ten-year } \\
\text { contract. Court cases followed detailing the } \\
\text { abuse of the presidency powers by Zuma. } \\
\text { Ultimately, Nxasana was ordered to repay } \\
\text { R17m and Zuma's appointed replacement, } \\
\text { Shawn Abrahams, was ordered to vacate office. } \\
\text { Constitutional Court found Zuma's actions to } \\
\text { be an abuse of power and in breach of his } \\
\text { constitutional obligations. }\end{array}$ & $\begin{array}{l}\text { - Cassim } \\
\text { Inquiry into } \\
\text { fitness of } \\
\text { Mxolisi } \\
\text { Nxasana to } \\
\text { hold office } \\
\text { of NDPP } \\
\text { initiated } \\
\text { by Zuma, } \\
\text { followed by } \\
\text { litigation }\end{array}$ & $\begin{array}{l}\text { - National } \\
\text { Prosecution } \\
\text { Authority }\end{array}$ \\
\hline $\begin{array}{l}\text { Political } \\
\text { killings in } \\
\text { KZN }\end{array}$ & $\begin{array}{l}\text { Established in } \\
\text { October } 2016 . \text { The } \\
\text { report was released } \\
\text { in May } 2018 .\end{array}$ & $\begin{array}{l}\text { On } 28 \text { October 2016, the Premier of the } \\
\text { Province of KwaZulu-Natal established a } \\
\text { Commission of Enquiry into the Underlying } \\
\text { Causes of the Murder of Politicians in KwaZulu- } \\
\text { Natal (KZN). }\end{array}$ & $\begin{array}{l}\text { - Moerane } \\
\text { Commission } \\
\text { of Enquiry }\end{array}$ & $\begin{array}{l}\text { - KZN Provincial } \\
\text { Government } \\
\text { - KZN Local } \\
\text { Governments }\end{array}$ \\
\hline
\end{tabular}




\begin{tabular}{|c|c|c|c|c|}
\hline $\begin{array}{l}\text { Case Study } \\
\text { in State } \\
\text { Capture }\end{array}$ & Status & Summary Description & $\begin{array}{l}\text { Investigation } \\
\text { Body / } \\
\text { Source of } \\
\text { Evidence } \\
\end{array}$ & $\begin{array}{l}\text { Government } \\
\text { Entity } \\
\text { Implicated }\end{array}$ \\
\hline \multicolumn{5}{|c|}{ Scandals Connected to Jacob Zuma, Guptas, Other Key Networks and ANC Politics } \\
\hline \multicolumn{5}{|c|}{ State Capture of State-Owned Enterprises and Government Departments } \\
\hline $\begin{array}{l}\text { Interference } \\
\text { in operations } \\
\text { at the SABC }\end{array}$ & $\begin{array}{l}\text { The Ad Hoc } \\
\text { Committee was } \\
\text { established in } \\
\text { November } 2016 \\
\text { and final report } \\
\text { was tabled on } \\
24 \text { February } 2017 .\end{array}$ & $\begin{array}{l}\text { Parliamentary Ad Hoc Committee on the } \\
\text { SABC Board Inquiry into mismanagement and } \\
\text { interference in SABC operations. Findings } \\
\text { include evidence of Minister Faith Muthambi's } \\
\text { interference in the organisation and editorial } \\
\text { interference, in the firing of SABC } 8 \text { who } \\
\text { protested censorship of the national broadcaster } \\
\text { (on instruction from COO Hlaudi Motsoeneng). It } \\
\text { should be noted that the inquiry was preceded } \\
\text { by an investigation by the Public Protector. } \\
\text { Details are contained in the } 2014 \text { report titled } \\
\text { When Governance and Ethics Fail. }\end{array}$ & $\begin{array}{l}\text { - Parliamen- } \\
\text { tary Inquiry } \\
\text { - Preceded by } \\
\text { an investi- } \\
\text { gation by } \\
\text { the Public } \\
\text { Protector }\end{array}$ & $\begin{array}{l}\text { - SABC } \\
\text { (Department } \\
\text { of Communi- } \\
\text { cation) }\end{array}$ \\
\hline \multirow[t]{2}{*}{$\begin{array}{l}\text { Passenger } \\
\text { Rail Agency } \\
\text { of South } \\
\text { Africa } \\
\text { (PRASA) }\end{array}$} & $\begin{array}{l}\text { Complaints were } \\
\text { lodged in } 2012 \\
\text { and the report } \\
\text { was released in } \\
\text { August } 2015 .\end{array}$ & $\begin{array}{l}\text { Several cases of "mismanagement and } \\
\text { irregularities" regarding various contracts. } \\
\text { Lucky Montana was CEO at the time. One of } \\
\text { the remedial actions stipulated that National } \\
\text { Treasury was to investigate all PRASA contracts } \\
\text { from } 2012 \text { onwards with a value of R10 million } \\
\text { or more. National Treasury implemented the } \\
\text { remedial action which resulted in several } \\
\text { investigations, the details of which were leaked } \\
\text { to the public. }\end{array}$ & $\begin{array}{l}\text { - Public } \\
\text { Protector's } \\
\text { Derailed } \\
\text { report on } \\
\text { PRASA } \\
\text { - Numerous } \\
\text { investiga- } \\
\text { tions }\end{array}$ & $\begin{array}{l}\text { - PRASA } \\
\text { - Department of } \\
\text { Transport }\end{array}$ \\
\hline & $\begin{array}{l}\text { In June } 2017, \\
\text { Parliament directed } \\
4 \text { committees to } \\
\text { investigate state } \\
\text { capture. Committee } \\
\text { hearings were not } \\
\text { completed. }\end{array}$ & $\begin{array}{l}\text { In terms of the parliamentary directive, the } \\
\text { Portfolio Committee on Transport was requested } \\
\text { to establish an Inquiry into State Capture at } \\
\text { PRASA. However, the Portfolio Committee noted } \\
\text { that PRASA was not mentioned in the Public } \\
\text { Protector's State of Capture report and decided } \\
\text { they would focus on the various investigation } \\
\text { reports produced for National Treasury (as } \\
\text { recommended in Derailed report). }\end{array}$ & $\begin{array}{l}\text { - Portfolio } \\
\text { Committee } \\
\text { on Transport }\end{array}$ & $\begin{array}{l}\text { - PRASA } \\
\text { - Department of } \\
\text { Transport }\end{array}$ \\
\hline $\begin{array}{l}\text { Eskom } \\
\text { Inquiry into } \\
\text { State Capture }\end{array}$ & $\begin{array}{l}\text { In June } 2017 \text {, } \\
\text { Parliament directed } \\
4 \text { committees } \\
\text { to investigate } \\
\text { state capture. } \\
\text { Public Enterprises } \\
\text { Committee } \\
\text { report on Eskom } \\
\text { was released in } \\
\text { November } 2018 .\end{array}$ & $\begin{array}{l}\text { Extensive hearings were held by the Committee } \\
\text { detailing much of the evidence presented in } \\
\text { the Public Protector's report. The Committee } \\
\text { presented recommendations and compiled } \\
\text { a final report detailing their findings. These } \\
\text { included findings that Ministers Lynne Brown } \\
\text { and Malusi Gigaba were negligent and had to } \\
\text { be held accountable. Also recommended that } \\
\text { criminal investigations be undertaken against } \\
\text { the relevant Eskom executives. }\end{array}$ & $\begin{array}{l}\text { - Parliamen- } \\
\text { tary Inquiry }\end{array}$ & $\begin{array}{l}\text { - Eskom } \\
\text { - Department } \\
\text { of Public } \\
\text { Enterprises }\end{array}$ \\
\hline $\begin{array}{l}\text { Nugent } \\
\text { Commission } \\
\text { - SARS } \\
\text { Inquiry }\end{array}$ & $\begin{array}{l}\text { The Inquiry was } \\
\text { constituted on } \\
24 \text { May } 2018 \text { and } \\
\text { the final report } \\
\text { was released in } \\
\text { December } 2018 .\end{array}$ & $\begin{array}{l}\text { Commission of Inquiry into tax administration } \\
\text { and governance by South African Revenue } \\
\text { Service (SARS). Tom Moyane was fired based on } \\
\text { the interim report released in September } 2018 . \\
\text { The inquiry found that Moyane, with the help of } \\
\text { consultancy company Bain, had implemented } \\
\text { restructuring of the organisation, resulting in } \\
\text { gross mismanagement and erosion of SARS. } \\
\text { Moyane motivated the restructuring based on } \\
\text { the "rogue unit" narrative that has been the } \\
\text { subject of several other debunked investigations } \\
\text { and the subject of much litigation. }\end{array}$ & $\begin{array}{l}\text { - Judicial } \\
\text { Commission } \\
\text { of Inquiry } \\
\text { - Court cases } \\
\text { around the } \\
\text { "rogue unit" } \\
\text { narrative }\end{array}$ & $\begin{array}{l}\text { - SARS } \\
\text { (National } \\
\text { Treasury) }\end{array}$ \\
\hline
\end{tabular}




\begin{tabular}{|c|c|c|c|c|}
\hline $\begin{array}{l}\text { Case Study } \\
\text { in State } \\
\text { Capture }\end{array}$ & Status & Summary Description & $\begin{array}{l}\text { Investigation } \\
\text { Body / } \\
\text { Source of } \\
\text { Evidence }\end{array}$ & $\begin{array}{l}\text { Government } \\
\text { Entity } \\
\text { Implicated }\end{array}$ \\
\hline \multicolumn{5}{|c|}{ Scandals Connected to Jacob Zuma, Guptas, Other Key Networks and ANC Politics } \\
\hline \multicolumn{5}{|c|}{ State Capture of State-Owned Enterprises and Government Departments } \\
\hline $\begin{array}{l}\text { Commission } \\
\text { of Inquiry } \\
\text { into Public } \\
\text { Investment } \\
\text { Corporation } \\
\text { (PIC) }\end{array}$ & $\begin{array}{l}\text { In October } 2018 \text {, } \\
\text { the Commission } \\
\text { was constituted, } \\
\text { and the final report } \\
\text { was released in } \\
\text { March } 2020 .\end{array}$ & $\begin{array}{l}\text { Commission of Inquiry into allegations of } \\
\text { impropriety regarding Public Investment } \\
\text { Corporation (PIC). There were extensive hearings } \\
\text { on various 'dodgy' deals the PIC entered } \\
\text { into and details of political and executive } \\
\text { interference in the operations and decision- } \\
\text { making processes of the investment agency. }\end{array}$ & $\begin{array}{l}\text { - Judicial } \\
\text { Commission } \\
\text { of Inquiry }\end{array}$ & $\begin{array}{l}\text { - PIC (National } \\
\text { Treasury) }\end{array}$ \\
\hline $\begin{array}{l}\text { South African } \\
\text { Social } \\
\text { Security } \\
\text { Agency } \\
\text { (SASSA) }\end{array}$ & $\begin{array}{l}\text { Various } \\
\text { Constitutional Court } \\
\text { cases from } 2011 \\
\text { to } 2018 \text { resulted } \\
\text { in removal of CPS } \\
\text { as service provider } \\
\text { to SASSA. }\end{array}$ & $\begin{array}{l}\text { In 2014, South African Social Security Agency's } \\
\text { (SASSA) } 2012 \text { contract with CPS was found } \\
\text { to be irregular and invalid, however, due to the } \\
\text { importance of ensuring beneficiaries received } \\
\text { grants, CPS continued to be the service } \\
\text { providers until } 2018 \text {. Following a March } 2017 \\
\text { ruling, the Constitutional Court instituted a } \\
\text { Section } 38 \text { Inquiry into Minister Bathabile } \\
\text { Dlamini's personal liability for the narrowly } \\
\text { averted grant payment crisis. }\end{array}$ & $\begin{array}{l}\text { Primary } \\
\text { sources: } \\
\text { - AllPay court } \\
\text { case } \\
\text { - Black Sash } \\
\text { court case }\end{array}$ & - SASSA \\
\hline $\begin{array}{l}\text { South African } \\
\text { Airways (SAA) } \\
\text { and SAA } \\
\text { Technical }\end{array}$ & $\begin{array}{l}\text { Court case } \\
\text { to have Dudu } \\
\text { Myeni declared a } \\
\text { delinquent director } \\
\text { was launched } \\
\text { in } 2017 .\end{array}$ & $\begin{array}{l}\text { Court case was launched in } 2017 \text { by Outa and } \\
\text { the SAA Pilots' Association (SAAPA) to declare } \\
\text { Myeni a delinquent director in terms of the } \\
\text { Companies Act, based on her actions while she } \\
\text { was chairperson of the SAA Board. In 2020, the } \\
\text { High Court declared Myeni a delinquent director } \\
\text { for life. A significant amount of new evidence } \\
\text { also emerged through the Zondo Commission, } \\
\text { outlining how the operations at SAA were } \\
\text { undermined and how Myeni and others abused } \\
\text { their positions of authority. }\end{array}$ & $\begin{array}{l}\text { - Court } \\
\text { papers } \\
\text { - Zondo } \\
\text { Commission }\end{array}$ & $\begin{array}{l}\text { - SAA } \\
\text { - SAA Technical }\end{array}$ \\
\hline $\begin{array}{l}\text { Gupta Family } \\
\text { Naturalisation }\end{array}$ & $\begin{array}{l}\text { In June } 2017, \\
\text { Parliament directed } \\
4 \text { committees to } \\
\text { investigate state } \\
\text { capture. Final } \\
\text { report was tabled } \\
14 \text { March } 2019 .\end{array}$ & $\begin{array}{l}\text { Portfolio Committee on Home Affairs Inquiry into } \\
\text { the Gupta Family Naturalisation was established } \\
\text { in terms of the Parliamentary directive. Hearings } \\
\text { formally started on } 12 \text { September 2018. Final } \\
\text { report was tabled on } 14 \text { March 2019. Questions } \\
\text { were raised around contracts with Visa } \\
\text { Facilitation Services. This matter is ongoing as } \\
\text { of December } 2020 \text {. }\end{array}$ & $\begin{array}{l}\text { - Portfolio } \\
\text { Committee } \\
\text { on Home } \\
\text { Affairs }\end{array}$ & $\begin{array}{l}\text { - Department of } \\
\text { Home Affairs }\end{array}$ \\
\hline $\begin{array}{l}\text { Inquiry into } \\
\text { State Capture } \\
\text { related to } \\
\text { Gupta-owned } \\
\text { mines }\end{array}$ & $\begin{array}{l}\text { In June } 2017, \\
\text { Parliament directed } \\
4 \text { committees } \\
\text { to investigate } \\
\text { state capture. }\end{array}$ & $\begin{array}{l}\text { Though the Committee drafted a term of } \\
\text { reference for the Inquiry, the activities of holding } \\
\text { hearings and consolidating the evidence never } \\
\text { materialised beyond questions being put to then } \\
\text { Minister Zwane. }\end{array}$ & $\begin{array}{l}\text { - Portfolio } \\
\text { Committee } \\
\text { on Mineral } \\
\text { Resources }\end{array}$ & $\begin{array}{l}\text { - Department } \\
\text { of Mineral } \\
\text { Resources }\end{array}$ \\
\hline
\end{tabular}




\begin{tabular}{|c|c|c|c|c|}
\hline $\begin{array}{l}\text { Case Study } \\
\text { in State } \\
\text { Capture }\end{array}$ & Status & Summary Description & $\begin{array}{l}\text { Investigation } \\
\text { Body / } \\
\text { Source of } \\
\text { Evidence }\end{array}$ & $\begin{array}{l}\text { Government } \\
\text { Entity } \\
\text { Implicated }\end{array}$ \\
\hline \multicolumn{5}{|c|}{ Scandals Connected to Jacob Zuma, Guptas, Other Key Networks and ANC Politics } \\
\hline \multicolumn{5}{|c|}{ State Capture of State-Owned Enterprises and Government Departments } \\
\hline \multirow{3}{*}{$\begin{array}{l}\text { Various } \\
\text { investigations } \\
\text { relating to } \\
\text { State Capture } \\
\text { at Eskom }\end{array}$} & 2015 & $\begin{array}{l}\text { In 2015, Dentons produced an interim report } \\
\text { on their investigations into Status of Business } \\
\text { and Challenges at Eskom. Their investigation } \\
\text { was halted. }\end{array}$ & - Eskom & - Eskom \\
\hline & \multirow[t]{2}{*}{2017} & $\begin{array}{l}\text { In 2017, PricewaterhouseCoopers (PwC) was } \\
\text { appointed by National Treasury to investigate } \\
\text { Eskom's Coal Procurement Processes. Damning } \\
\text { findings were made in relation to Gupta-owned } \\
\text { Tegeta mine contracts and poor coal quality. }\end{array}$ & - Eskom & - Eskom \\
\hline & & $\begin{array}{l}\text { G9 was contracted by Eskom to investigate } \\
\text { the Trillian/McKinsey contracts. Interim report } \\
\text { presented to Board of Eskom in August } 2017 . \\
\text { The investigation remained incomplete, and } \\
\text { no report is available in the public domain. } \\
\text { Evidence from the investigation was presented } \\
\text { in the Parliamentary Inquiry into Eskom } \\
\text { State Capture. }\end{array}$ & $\begin{array}{l}\text { - National } \\
\text { Treasury }\end{array}$ & - Eskom \\
\hline $\begin{array}{l}\text { National } \\
\text { Treasury } \\
\text { Fundudzi } \\
\text { reports, } \\
\text { related to } \\
\text { Eskom and } \\
\text { Transnet (x3) }\end{array}$ & $\begin{array}{l}\text { Final reports } \\
\text { compiled in } \\
\text { November } 2018 \\
\text { and released to } \\
\text { the public shortly } \\
\text { thereafter. }\end{array}$ & $\begin{array}{l}\text { Investigations requested by National Treasury } \\
\text { of alleged corruption at Transnet and Eskom. } \\
\text { The three reports focused on Eskom (general), } \\
\text { the contracts related to Trillian/McKinsey and } \\
\text { Transnet Locomotives. }\end{array}$ & $\begin{array}{l}\text { - National } \\
\text { Treasury } \\
\text { Fundudzi }\end{array}$ & $\begin{array}{l}\text { - Eskom } \\
\text { - Transnet }\end{array}$ \\
\hline \multirow[t]{2}{*}{$\begin{array}{l}\text { Transnet } \\
\text { Locomotive } \\
\text { Contracts }\end{array}$} & \multirow[t]{2}{*}{$\begin{array}{l}\text { Investigations } \\
\text { commenced in } \\
\text { December } 2017 \\
\text { and reports on } \\
\text { findings submitted } \\
\text { during } 2018 .\end{array}$} & $\begin{array}{l}\text { Werksmans Attorneys was appointed in } \\
\text { December } 2017 \text { to undertake an investigation } \\
\text { into the } 1064 \text { Transnet Locomotives } \\
\text { procurement process, however, the investigation } \\
\text { was halted. No report in the public domain. }\end{array}$ & - Werksmans & - Transnet \\
\hline & & $\begin{array}{l}\text { Mncedisi Ndlovu \& Sedumedi (MNS) Attorneys } \\
\text { was then appointed to investigate } 1064 \\
\text { locomotives procurement process. The report } \\
\text { is not in the public domain, but media indicates } \\
\text { that recommendations mirror the Werksmans' } \\
\text { findings and recommends that Molefe face } \\
\text { criminal charges. }\end{array}$ & $\begin{array}{l}\text { - Mncedisi } \\
\text { Ndlovu \& } \\
\text { Sedumedi }\end{array}$ & - Transnet \\
\hline $\begin{array}{l}\text { Inquiry into } \\
\text { State Capture } \\
\text { at Transnet } \\
\text { and Denel }\end{array}$ & $\begin{array}{l}\text { In June } 2017, \\
\text { Parliament directed } \\
4 \text { committees to } \\
\text { investigate state } \\
\text { capture. Committee } \\
\text { hearings were not } \\
\text { completed. }\end{array}$ & $\begin{array}{l}\text { A detailed information booklet was prepared } \\
\text { in relation to Transnet, however, hearings were } \\
\text { not held before the end of term of Parliament. } \\
\text { Following National elections in 2019, it } \\
\text { was decided that outstanding Inquiries into } \\
\text { state capture be postponed indefinitely until } \\
\text { conclusion of the Zondo Commission. }\end{array}$ & $\begin{array}{l}\text { - Portfolio } \\
\text { Committee } \\
\text { on Public } \\
\text { Enterprises }\end{array}$ & $\begin{array}{l}\text { - Transnet } \\
\text { - Denel }\end{array}$ \\
\hline
\end{tabular}




\begin{tabular}{|c|c|c|c|c|}
\hline $\begin{array}{l}\text { Case Study } \\
\text { in State } \\
\text { Capture }\end{array}$ & Status & Summary Description & $\begin{array}{l}\text { Investigation } \\
\text { Body / } \\
\text { Source of } \\
\text { Evidence }\end{array}$ & $\begin{array}{l}\text { Government } \\
\text { Entity } \\
\text { Implicated }\end{array}$ \\
\hline \multicolumn{5}{|c|}{ Scandals Connected to Jacob Zuma, Guptas, Other Key Networks and ANC Politics } \\
\hline \multicolumn{5}{|c|}{ Law Enforcement and the Security Cluster } \\
\hline $\begin{array}{l}\text { Enquiry into } \\
\text { Jiba and } \\
\text { Mrwebi's } \\
\text { fitness to } \\
\text { hold office } \\
\text { at NPA }\end{array}$ & $\begin{array}{l}\text { Established in } \\
\text { November } 2018 . \\
\text { Report was issued } \\
\text { in April } 2019 .\end{array}$ & $\begin{array}{l}\text { Presidential Enquiry into the fitness to hold } \\
\text { office of suspended NPA senior advocates } \\
\text { Nomgcobo Jiba and Lawrence Mrwebi. NPA's } \\
\text { deputy head Jiba, and Mrwebi, the head of } \\
\text { the Specialised Commercial Crimes Unit, were } \\
\text { suspended in October } 2018 \text { by President Cyril } \\
\text { Ramaphosa. The Inquiry was headed by retired } \\
\text { Constitutional Court Justice Yvonne Mokgoro. } \\
\text { Jiba and Mrwebi were accused of improper } \\
\text { conduct in their handling of cases involving } \\
\text { former crime intelligence head Richard Mdluli, } \\
\text { as well as former KwaZulu-Natal Hawks boss } \\
\text { Johan Booysen. }\end{array}$ & $\begin{array}{c}\text { - Mokgoro } \\
\text { Enquiry }\end{array}$ & $\begin{array}{l}\text { - } \text { National } \\
\text { Prosecuting } \\
\text { Authority }\end{array}$ \\
\hline $\begin{array}{l}\text { High-Level } \\
\text { Review Panel } \\
\text { on the State } \\
\text { Security } \\
\text { Agency (SSA) }\end{array}$ & $\begin{array}{l}\text { Established in June } \\
2018 \text { and final } \\
\text { report was sent to } \\
\text { the President in } \\
\text { December } 2018 .\end{array}$ & $\begin{array}{l}\text { The High-Level Review Panel into the SSA } \\
\text { was established by President Ramaphosa in } \\
\text { June 2018. The key finding was a serious } \\
\text { politicisation and factionalisation of the } \\
\text { intelligence community over the past decade } \\
\text { or more. This resulted in "an almost complete } \\
\text { disregard for the Constitution, policy, legislation } \\
\text { and other prescripts, and [turned] our civilian } \\
\text { intelligence community into a private resource } \\
\text { to serve the political and personal interests of } \\
\text { particular individuals" (High-Level Review Panel } \\
\text { on the SSA, 2018, p.ii). }\end{array}$ & $\begin{array}{l}\text { - Review } \\
\text { Panel } \\
\text { established } \\
\text { by President } \\
\text { Ramaphosa }\end{array}$ & - SSA \\
\hline $\begin{array}{l}\text { Various court } \\
\text { cases against } \\
\text { persons } \\
\text { within law } \\
\text { enforcement }\end{array}$ & Ongoing. & $\begin{array}{l}\text { Though testimony and evidence have been } \\
\text { presented at the Zondo Commission, it is } \\
\text { understood that no definitive findings will be } \\
\text { made regarding the capture of law enforcement } \\
\text { under the Zuma administration. Since } 2012 \\
\text { onwards, there were several court cases } \\
\text { that were pursued against individuals in law } \\
\text { enforcement, all of which have been either } \\
\text { dismissed or withdrawn. Most noteworthy are } \\
\text { the cases involved, amongst others: Anwa } \\
\text { Dramat and Shadrack Sibiya of the Hawks } \\
\text { (and Robert McBride from Independent Police } \\
\text { Investigative Directorate [IPID]) for allegations } \\
\text { related to the "Zimbabwean rendition" matter; } \\
\text { Johan Booysen for alleged racketeering as part } \\
\text { of "Cato Manor hit squad"; and the various } \\
\text { senior officials accused of being part of the } \\
\text { "rogue" intelligence unit at SARS. Other court } \\
\text { cases that have provided significant evidence } \\
\text { indicating the capture of law enforcement relate } \\
\text { to the irregular appointed allies of the Shadow } \\
\text { State capture network or the irrational removal } \\
\text { of potential opponents holding senior positions } \\
\text { in law enforcement. Example is the irregular } \\
\text { removal of Mxolisi Nxasana as National Director } \\
\text { of Public Prosecutions (NDPP). }\end{array}$ & $\begin{array}{l}\text { - Various } \\
\text { court cases, } \\
\text { proceedings } \\
\text { in Parlia- } \\
\text { ment } \\
\text { - Zondo } \\
\text { Commission }\end{array}$ & $\begin{array}{l}\text { - NPA } \\
\text { - SAPS } \\
\text { - Hawks } \\
\text { - IPID }\end{array}$ \\
\hline
\end{tabular}




\begin{tabular}{|c|c|c|c|c|}
\hline $\begin{array}{l}\text { Case Study } \\
\text { in State } \\
\text { Capture }\end{array}$ & Status & Summary Description & $\begin{array}{l}\text { Investigation } \\
\text { Body / } \\
\text { Source of } \\
\text { Evidence }\end{array}$ & $\begin{array}{l}\text { Government } \\
\text { Entity } \\
\text { Implicated }\end{array}$ \\
\hline \multicolumn{5}{|c|}{ Scandals Connected to Jacob Zuma, Guptas, Other Key Networks and ANC Politics } \\
\hline \multicolumn{5}{|c|}{ Investigations concerning Private Sector } \\
\hline $\begin{array}{l}\text { Budlender } \\
\text { report on } \\
\text { Trillian }\end{array}$ & $\begin{array}{l}\text { Released in } \\
\text { June } 2017 .\end{array}$ & $\begin{array}{l}\text { Trillian Holdings Board appointed Geoff } \\
\text { Budlender SC to undertake investigations into } \\
\text { State Capture allegations at Trillian Capital. } \\
\text { Detailed accounts from whistle-blowers } \\
\text { highlighted how information was withheld by } \\
\text { senior management at Trillian. }\end{array}$ & - Trillion & - Eskom \\
\hline $\begin{array}{l}\text { Collapse of } \\
\text { VBS Mutual } \\
\text { Bank }\end{array}$ & $\begin{array}{l}\text { Investigation } \\
\text { launched in } \\
\text { April } 2018 \text { and } \\
\text { the report was } \\
\text { released in } \\
\text { October } 2018 .\end{array}$ & $\begin{array}{l}\text { Minister of Finance placed VBS under } \\
\text { curatorship with effect from } 11 \text { March 2018. In } \\
\text { April 2018, the Deputy Governor of the South } \\
\text { African Reserve Bank instituted an investigation } \\
\text { into VBS. The outcomes of the investigation } \\
\text { showed blatant fraud and corruption by senior } \\
\text { executives/Board and how they extracted } \\
\text { money from the bank. Municipal funds were } \\
\text { illegally deposited with VBS (senior ANC and } \\
\text { EFF politicians have been implicated). }\end{array}$ & $\begin{array}{l}\text { - SARB } \\
\text { investiga- } \\
\text { tion report } \\
\text { VBS Mutual } \\
\text { Bank - The } \\
\text { Great Bank } \\
\text { Heist }\end{array}$ & $\begin{array}{l}\text { - Several } \\
\text { Provincial and } \\
\text { Municipal } \\
\text { Officials } \\
\text { (Limpopo } \\
\text { Government) } \\
\text { - SOEs } \\
\text { (particularly } \\
\text { PRASA) }\end{array}$ \\
\hline $\begin{array}{l}\text { SA Institute } \\
\text { of Chartered } \\
\text { Accountants' } \\
\text { (SAICA) } \\
\text { investigation } \\
\text { into KPMG }\end{array}$ & $\begin{array}{l}\text { Final report was } \\
\text { handed to SAICA in } \\
\text { December } 2018 .\end{array}$ & $\begin{array}{l}\text { SA Institute of Chartered Accountants (SAICA) } \\
\text { established an Inquiry to investigate state } \\
\text { capture related allegations of misconduct of its } \\
\text { members who worked for KPMG. The Inquiry } \\
\text { chaired by advocate Dumisa Ntsebeza held } \\
\text { public hearings and handed its final report to } \\
\text { SAICA in December 2018. Indications are that } \\
\text { the final report will not be made public until all } \\
\text { investigations and disciplinary hearings have } \\
\text { been finalised. }\end{array}$ & - SAICA & - Guptas \\
\hline Bell Pottinger & $\begin{array}{l}2017 \text { investigation } \\
\text { by PRCA. }\end{array}$ & $\begin{array}{l}\text { In 2016, the Guptas appointed British PR } \\
\text { company, Bell Pottinger, who developed and } \\
\text { promoted a campaign that underpinned the RET } \\
\text { and WMC narratives. In 2017, there was an } \\
\text { independent law firm review by Herbert Smith } \\
\text { Freehills resulting in Bell Pottinger's expulsion } \\
\text { from the Public Relations and Communications } \\
\text { Association (PRCA). }\end{array}$ & $\begin{array}{l}\text { - PRCA } \\
\text { - GuptaLeaks } \\
\text { - Ongoing } \\
\text { research } \\
\text { on disinfor- } \\
\text { mation }\end{array}$ & - Guptas \\
\hline
\end{tabular}

